\title{
A review of the non-metallic Osmia (Melanosmia) found in North America, with additional notes on palearctic Melanosmia (Hymenoptera, Megachilidae)
}

\author{
Molly G. Rightmyer ${ }^{1, \dagger}$, Terry Griswold ${ }^{1, \ddagger}$, Michael S. Arduser ${ }^{2, \S}$ \\ I USDA-ARS Bee Biology and Systematics Laboratory, BNR 244 UMC 5310, Utah State University, Logan \\ UT, 84322-5310 USA 2 Missouri Department of Conservation, 2360 Highway D, St. Charles MO 63304 \\ † urn:lsid:zoobank.org:author:90A04B61-0B07-4F3F-8F9E-DDCBDC108314 \\ † urn:lsid:zoobank.org:author:80DCC2BA-6D2D-449B-83DA-08BB71DBE589 \\ § urn:lsid:zoobank.org:author:974ECADF-F8E5-423C-937B-437A70ACDE44 \\ Corresponding author: Terry Griswold (terry.griswold@ars.usda.gov)
}

Academic editor: Michael Engel| Received 25 May 2010 | Accepted 15 July 2010 | Published 7 October 2010

urn:lsid:zoobank.org:pub:97526239-5675-43A8-98EF-9AC2F71066BF

Citation: Rightmyer MG, Griswold T, Arduser MS (2010) A review of the non-metallic Osmia (Melanosmia) found in North America, with additional notes on palearctic Melanosmia (Hymenoptera, Megachilidae). ZooKeys 60: 37-77. doi: 10.3897/zookeys.60.484

\begin{abstract}
We review the six species of non-metallic Osmia (Melanosmia) found in North America, including the description of two new species found in Canada and the northern United States: Osmia (Melanosmia) aquilonaria sp. n., and Osmia (Melanosmia) nearctica sp. n., respectively belonging to the inermis and xanthomelana species groups. We additionally provide keys to the non-metallic Melanosmia found in North America, and update keys to the palearctic Melanosmia based on study of the type specimens of Osmia disjuncta Tkalců, O. ephippiata Smith, O. ishikawai Hirashima, and O. pamirensis Gussakovskij.
\end{abstract}

\section{Keywords}

Bee, Apoidea, Megachilinae, Osmiini

Copyright M.G. Rightmyer,T. Griswold, M.S.Arduser. This is an open access article distributed under the terms of the Creative Commons Attribution License, which permits unrestricted use, distribution, and reproduction in any medium, provided the original author and source are credited. 


\section{Introduction}

This is a treatment of the members of the subgenus Melanosmia (sensu Michener 2007) that lack any metallic blue or green coloration on the integument of the mesosoma and metasoma (the head also usually lacks metallic blue or green coloration, although there is a hint of such color in the head of some males). For this reason, some workers informally refer to such species as the "dark Osmia." As treated herein, the group roughly corresponds to Melanosmia s. str. as used by Sandhouse (1939), excluding O. bucephala Cresson (1864), which we have excluded based on the slight metallic blue sheen found throughout the body of this species. It is currently unknown if the "dark Osmia" as a group has any phylogenetic standing; our decision to assemble and give taxonomic treatment to these species is based solely on the ease of distinguishing its members. In addition, certain species in this group are distributed in both the Eastern and Western Hemispheres, without, as far as we know, having been introduced by human activity. Other holarctic species of Osmia are rare and known to be human introductions. With few exceptions, most non-metallic Melanosmia are distributed in northern temperate to borealalpine regions, which possibly facilitated the widespread distribution of some species via Beringia.

As currently understood, the "dark Osmia" group found in North America is comprised of four holarctic species plus two new species apparently restricted to North America, for a total of six species. In addition, some (but not all) females of Osmia (Melanosmia) tersula Cockerell (1912) mostly lack a metallic blue or green sheen to their integument, and are therefore included in the key to non-metallic Melanosmia below.

Given the holarctic distribution of many non-metallic Melanosmia, there is a possibility that the two new North American species described herein are already known from the Palearctic. In order to avoid producing new junior synonyms, it is necessary to understand the 20 species of Melanosmia known from the Palearctic (Ungricht et al. 2008; Müller 2010) (Table 1). Unfortunately, not all species are well described in the literature and the two species described by Wu (O. nigroscopula Wu 1982 and O. jilinensis Wu 2004) are unknown to us although we attempted to borrow the holotype material.

Of the remaining 18 species of palearctic Melanosmia, three species (O. alticola Benoist 1922, O. maritima Friese 1885, and O. xanthomelana Kirby 1802) were placed in the xanthomelana species group by Tkalců (1983) due to the shared swollen gonoforceps of the males and the shining propodeal triangle (metapostnotum) of the females. Tkalců (1983) recognized a second group of palearctic Melanosmia, the inermis species group, whose members have relatively thin gonoforceps in males and dull posterior surface of the propodeum and propodeal triangle in females. The species that have been explicitly placed in the inermis species group (Tkalců 1983; Müller 2002, 2010) are as follows: O. inermis (Zetterstedt 1838); O. laticeps Thomson 1872; O. parietina Curtis 1828; O. pilicornis Smith 1846; O. steinmanni Müller 2002; O. svenssoni Tkalců 1983; and O. uncinata Gerstäcker 1869. Osmia disjuncta Tkalců 1995, was originally described as closely related to $O$. parietina and $O$. laticeps (as $O$. hyperborea), and upon examination of the female holotype we conclude that it also belongs to the inermis species group. 
Table I. Palearctic species of Osmia (Melanosmia), with holarctic species in bold.

\begin{tabular}{|c|c|c|c|}
\hline O. (MELANOSMIA) SPECIES & SPECIES GROUP & INTEGUMENT TYPE $^{\dagger}$ & EXAMINED MATERIAL $^{\ddagger}$ \\
\hline 1. O. alticola Benoist & $\begin{array}{l}\text { xanthomelana, } \\
\text { (based on Tkalců, } \\
1983 \text { ) }\end{array}$ & $\begin{array}{l}\text { faint metallic sheen } \\
\text { in } \widehat{\partial} \text { (A. Müller, } \\
\text { pers. comm.) }\end{array}$ & None \\
\hline 2. O. disjuncta Tkalců & inermis & non-metallic & q Holotype and $q, \widehat{\delta}$ paratyp \\
\hline 3. O. ephippiata Smith ${ }^{\S}$ & $\begin{array}{l}\text { xanthomelana? } \\
\text { (based on body } \\
\text { size and mandible) }\end{array}$ & non-metallic & O Holotype \\
\hline 4. O. inermis (Zetterstedt) & inermis & non-metallic & O,$\widehat{o}$ non-type specimens \\
\hline 5. O. ishikawai Hirashima & inermis & non-metallic & q Holotype \\
\hline 6. O. jilinensis $\mathrm{Wu}$ & $?$ & $\begin{array}{l}\text { non-metallic (based } \\
\text { on Wu, 2005) }\end{array}$ & None \\
\hline 7. O. laticeps Thomson & inermis & non-metallic & †, $\widehat{\jmath}$ non-type specimens \\
\hline 8. O. maritima Friese & xanthomelana & non-metallic & ㅇ, ô non-type specimens \\
\hline 9. O. melanota Morawitz & $?$ & $\begin{array}{l}\text { metallic (based on } \\
\text { Morawitz, 1888) }\end{array}$ & None \\
\hline $\begin{array}{l}\text { 10. O. nigriventris } \\
\text { (Zetterstedt) }\end{array}$ & nigriventris & non-metallic & $\begin{array}{l}\text { + specimens compared with } \\
\text { syntypes of } O \text {. corticalis by TG; } \\
0, \hat{X} \text { non-type specimens }\end{array}$ \\
\hline 11. O. nigroscopula $\mathrm{Wu}$ & $?$ & $\begin{array}{l}\text { non-metallic (based } \\
\text { on Wu, 2005) }\end{array}$ & None \\
\hline 12. O. pamirensis Gussakovskij & xanthomelana & slight metallic sheen & O Syntype \\
\hline 13. O. parietina Curtis & inermis & slight metallic sheen & + , non-type specimens \\
\hline 14. O. pilicornis Smith & inermis & $\begin{array}{l}\text { faint metallic sheen } \\
\text { in } \hat{0}\end{array}$ & $\begin{array}{l}\text { }+ \text {, } \text { specimens compared with } \\
\text { syntypes by TG }\end{array}$ \\
\hline 15. O. recta Peréz & $?$ & $?$ & None \\
\hline 16. O. steinmanni Müller & inermis & $\begin{array}{l}\text { faint metallic sheen } \\
\text { in } \hat{0}\end{array}$ & ○, ô Paratypes \\
\hline 17. O. svenssoni $\mathrm{Tkalců}$ & inermis & non-metallic & ㅇ, $\widehat{o}$ Paratypes \\
\hline 18. O. thoracica Radoszkowski & xanthomelana? & non-metallic? & O non-type specimen \\
\hline 19. O. uncinata Gerstäcker & inermis & non-metallic & $\begin{array}{l}\text { }, \hat{\jmath} \text { specimens compared with } \\
\text { syntypes by } \mathrm{TG} ; \text {; }, \hat{\jmath} \text { non-type } \\
\text { specimens }\end{array}$ \\
\hline 20. O. xanthomelana (Kirby) & xanthomelana & non-metallic & $\begin{array}{l}+ \text { specimen compared with } \\
\text { syntypes by TG; } \$, \lambda \text { non-type } \\
\text { specimens }\end{array}$ \\
\hline
\end{tabular}

† "Integument type" refers to the presence or absence of metallic blue or green coloration. $¥$ "Examined material" gives details of material examined for this study; information gathered from the literature or personal communication, and not based on examined material, is noted with citations in the table. § Distinctive characters of the O. ephippiata holotype are the following: mesepisternum and metasomal terga (including what is visible on T1) with entirely black hairs; mandible with parallel outer and condylar ridges; mandible with third tooth partially obscured by debris, but apparently more or less triangular between second and fourth teeth. The holotype of $O$. ephippiata has the metasoma glued to the mesosoma, so it is not currently possible to determine the sculpturing of its propodeum or declining anterior surface of T1; also, part of the dorsal surface of T1 is obscured by the glue. However, Tkalců (1983: 155) was able to examine the anterior surface of T1 in 1965, and he commented that it is distinctly shining. This observation was confirmed by George Else in 1977 (ibid). | Female specimen of $O$. thoracica Radoszkowsi from Hakkari, Turkey, identified by K. Warncke. 
Müller (2010) segregated O. nigriventris (Zetterstedt 1838) into a third species group; this classification scheme highlights some unusual characteristics of $O$. nigriventris (e.g., the extremely swollen clypeal margin of the female and laterally reflexed posterior terga of the male). These unusual features are shared with the North American species $O$. bucephala, a species that has further apomorphies that have obscured its taxonomic placement within Osmia.

The remaining species of palearctic Melanosmia have received less treatment in recent revisions and are thus considerably less well-known. They are O. ephippiata Smith 1879, O. ishikawai Hirashima 1973, O. melanota Morawitz 1888, O. pamirensis Gussakovskij 1930, O. recta Pérez 1902, and O. thoracica Radoszkowski 1874. Of these, we were able to exclude $O$. melanota from consideration as a possible component of the North American fauna due to the original description of the type material as dark metallic blue (Morawitz 1888, p. 243, 244). Osmia recta can also be excluded due to the fact that Pérez (1902, p. 63) described the holotype male as having two submedial tufts of long, blackish-grey hairs on T3 and T4; in addition, the species' known distribution is in Algeria, quite unlike the more northern distribution of the known holarctic species.

Of the palearctic Melanosmia not treated by Tkalců $(1983,1995)$ or Müller (2002), we have seen the holotype specimens of O. ephippiata and O. ishikawai. We have also examined a female syntype of $O$. pamirensis, and one of us (TG) has additionally seen the type series of two males and nine females of $O$. pamirensis at the Russian Academy, St. Petersburg in 1984 (although, according to notes made by TG at the time of his visit, the males of the type series appear not to be conspecific). Tkalcu (1983) did not treat females of $O$. laticeps (as O. hyperborea) in his revision of palearctic Melanosmia; the female of this species was diagnosed by Haeseler (1999). Herein we give further description of the female of $O$. laticeps and include it in an updated key to palearctic Melanosmia based on Tkalců $(1983,1995)$ and Müller (2002).

\section{Materials and methods}

The morphological terminology used herein follows that proposed by Michener (2007), with the exception of the following terms: flagellar segment instead of flagellomere, and basitarsal segment instead of basitarsus; in addition, we follow sculpture and punctation terminology proposed by Harris (1979). Mandibular teeth are numbered from ventral-most tooth to dorsal-most tooth. Thus, the ventral-most tooth is the first tooth and the next ventral-most tooth is the second. In the species treated herein, between the second and dorsal-most tooth is a smaller, slightly more inset, cutting edge extending from the dorsal-most tooth, here called the third tooth. The dorsal-most tooth is the fourth tooth.

The following morphological abbreviations are used: flagellar segment (F), metasomal tergum (T), metasomal sternum (S), and ocellar diameter (OD). Measurements are given for the holotype specimen, with the observed range from other specimens following in parentheses. 
Full label data are given for all specimens of new species. Label data of examined material for the remaining species were summarized at the county level or its equivalent, along with date, floral record, and altitude (if given). The following abbreviations are used for specimen repositories, with individuals associated with those repositories following in parentheses:

Boulder University of Colorado, Boulder CO (V. Scott)

Corvalus Oregon State University, Corvallis OR (C. Marshall)

Davis University of California, Davis CA (S. Heydon)

Logan USDA Bee Biology and Systematics Laboratory, Logan UT (T. Griswold, H. Ikerd)

Logan-TG Personal collection of T. Griswold, Logan UT

Moscow University of Idaho, Moscow ID (J. B. Johnson, F. M. Merickel)

New York American Museum of Natural History, New York NY (J. S. Ascher, J. G. Rozen, Jr.)

Oтtawa Canadian National Collection, Ottawa (L. Dumouchel, P. LeClair)

San Francisco California Academy of Sciences, San Francisco CA (W. Pulawski, R. Zuparko)

St. Charles Missouri Department of Conservation, St. Charles MO (M. Arduser)

Toronto Royal Ontario Museum, Toronto Ontario (B. Hubley)

Uppsala Uppsala University, Sweden (B. G. Svensson)

Victoria Royal British Columbia Museum, Victoria B. C. (R. Cannings)

Specimens were examined and measured using a Leica MZ12 dissection microscope and ocular micrometer. Photomicrographs were taken using a Keyence Digital Imaging System.

\section{Key to North American Females of Non-Metallic Osmia (Melanosmia)}

[Modified from Tkalců 1983, 1995]

1. Apical margin of clypeus strongly thickened (Figs 11, 12)

- Apical margin of clypeus more or less flat (Figs 4, 6) ..................................2

2. Ventral margin of mandible with distinct tooth (Fig. 52) (propodeal triangle strongly granulose, Fig. 56; mandible with apical margin about a third wider than median width, Fig. 4)

O. inermis (Zetterstedt)

- Ventral margin of mandible sometimes slightly swollen medially, but lacking

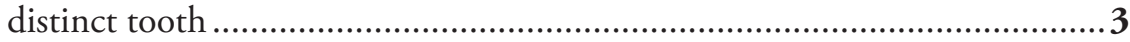

3. Propodeal triangle strongly granulose (Figs 16, 56) ...............................4 Propodeal triangle with more or less shining ventral area (Figs 36, 57) (mandible with apical width 1.5 times greater than median width) [xanthomelana species group] 
4. T2-T3 with apical impunctate bands nearly one-third of postgradular width O. tersula Cockerell (western form)

- $\quad$ T2-T3 with apical impunctate bands lacking or about one-fifth of postgradular width [inermis species group] ............................................................

5. Mandible with third tooth broad, neither strongly protruding nor strongly separated from fourth tooth (Fig. 6), with condylar and outer ridges strongly converging apically (Fig. 5); mesepisternum with white to pale yellow hairs; T1 dorsal surface with distinct punctures (Fig. 58) ..... O. laticeps Thomson Mandible with third tooth symmetrically triangular, broadly separated from both fourth and second teeth by acute-angled and broad indentation (Fig. 2), with condylar and outer ridges nearly parallel to weakly converging apically (Fig. 1); mesepisternum with hairs predominantly blackish, only on its most anterior and dorsal part with narrow zone bright yellowish-brown; T1 dorsal surface granulose/papillate, with punctures less strongly impressed (Fig. 17) ...

O. aquilonaria Rightmyer, Griswold, \& Arduser, sp. n.

6. Mandible with third tooth in same plane as second and fourth teeth, lacking distinct carina separating it from second and fourth teeth (Fig. 10); outer hind tibial spur weakly curved apically; clypeus with apical truncate process with distinct lateral angle, margin lateral of truncation distinctly stairstepped (Fig. 35); hair fringe of galea in dorsal view shorter than width of malar space at mandibular condyle

O. nearctica Rightmyer, Griswold, \& Arduser, sp. n.

- Mandible with third tooth distinctly recessed between second and fourth teeth, with carina separating it from second and fourth teeth (Fig. 8); outer hind tibial spur strongly curved apically; clypeus with apical truncation not distinctly angled laterally, margin lateral of truncation sinuate but not distinctly stairstepped (Fig. 55); hair fringe of galea in dorsal view as long as width of malar space at mandibular condyle......

O. maritima Friese

\section{Key to North American Males of Non-Metallic Osmia (Melanosmia)}

[Modified from Tkalců 1983, 1995; and Müller 2002]

1. T5 and T6 with apicolateral angles strongly reflexed laterally (Fig. 53) O. nigriventris (Zetterstedt)

- $\quad$ T5 and T6 with apicolateral angles not or only weakly reflexed laterally .....2

2. Outer margin of gonoforceps preapically with semicircular widening, at this point gonoforceps appearing nearly twice as broad as its narrowest width (Figs 45, 49, 50, 64) [xanthomelana species group]

- $\quad$ Outer margin of gonoforceps preapically not or only weakly widened, at this point gonoforceps at most little broader than at its narrowest width (Figs 26, 30, 31) [inermis species group] 
3. Flagellar segments on ventral surface with hairs microscopic; S2 with midapical margin not emarginate

O. nearctica Rightmyer, Griswold, \& Arduser, sp. n.

- $\quad$ Flagellar segments on ventral surface with sparse hairs, their length about half the flagellar segment width; S2 with midapical edge weakly emarginate.

O. maritima Friese (based on observed palearctic material only)

4. S4 with hooked bristles both along apical margin and on premarginal area, along apical margin the bristles oriented horizontally and on premarginal area directed increasingly vertically (Figs 24, 25)

O. aquilonaria Rightmyer, Griswold, \& Arduser, sp. n.

- $\quad$ S4 with midapical hairs unmodified, without hooked bristles (Figs 60, 61).... 5

5. S4 with apical margin truncate, medially with strong emargination and distinct, rounded lobes lateral to emargination (Fig. 60); declining basal portion of T1 densely shagreened, only with a silky luster.... O. inermis (Zetterstedt)

- $\quad$ S4 with apical margin more or less evenly convex, lacking strong emargination at midpoint and distinct sublateral lobes (Fig. 61); declining basal portion of T1 shining, at most superficially shagreened in small areas...... O. laticeps Thomson

\section{Key to Eastern Hemisphere Females of Osmia (Melanosmia)}

[Modified from Tkalců 1983, 1995; Haeseler 1999; and Müller 2002. Species absent from keys in the treatments cited above and for which we have seen no specimens are excluded: O. jilinensis, O. melanota, O. nigroscopula, and O. recta. (See Table 1) ].

1. Apical margin of clypeus strongly thickened .... O. nigriventris (Zetterstedt)

- Apical margin of clypeus more or less flat. 2

2. Propodeum shiny, propodeal triangle nearly completely polished or at least along sides with shiny area. Body length at least $11 \mathrm{~mm}$ [xanthomelana species group]

- $\quad$ Propodeum and propodeal triangle completely shagreened and dull; body length at most $10 \mathrm{~mm}$ [inermis species group]

3. T2 with impunctate apical margin medially rather broad (ca. length of F10); T4 polished (excluding the shagreened, impunctate apical margin)............. 4

- $\quad$ T2 with impunctate apical margin narrower; T4 more or less shagreened throughout

4. Integument with weak metallic sheen; mandible with rather weak, nearly absent, carina separating third tooth from second and fourth

O. pamirensis Gussakovskij

- $\quad$ Integument lacking metallic sheen; mandible with relatively strong carina separating third tooth from second and fourth

O. maritima Friese, O. ephippiata Smith, and O. thoracica

Radoszkowski [see Table 1 for further comments] 
5. Mandible with third tooth directed in same plane as second and fourth teeth, not set off from dorsal surface of mandible by carina; T2 with hairs medially on disc relatively long (ca. 640 micrometers), predominantly yellow-brown....

O. xanthomelana (Kirby)

- Mandible with third tooth directed slightly towards inner surface of mandible, set off from dorsal surface of mandible by carina extending from inner margins of second and fourth teeth; T2 with hairs medially on disc relatively short (ca. 400 micrometers), entirely black

O. alticola Benoist

6. Declining basal portion of T1 densely shagreened, only with a silky luster....7

- $\quad$ Declining basal portion of T1 shining, at most superficially shagreened in

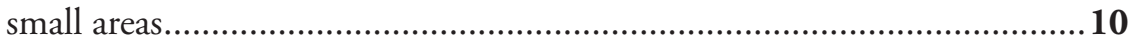

7. Mandible with third tooth broad, not strongly separated from fourth tooth; forewing with veins $\mathrm{cu}-\mathrm{v}$ and $\mathrm{M}$ intersecting vein $\mathrm{M}+\mathrm{Cu}$ at the same place...8

- $\quad$ Mandible with third tooth more triangular; forewing with cu-v intersecting vein $\mathrm{M}+\mathrm{Cu}$ at a point distal to that of $\mathrm{M}$

8. Mandible on its inferior inner margin with prominent, asymmetrically triangular tooth; third tooth nearly filling entire space between second and fourth teeth; clypeus in profile only moderately convex

O. inermis (Zetterstedt) and O. ishikawai Hirashima

- Mandible on its inferior inner margin nearly straight, without tooth; third tooth separated from second by indentation nearly one-third of entire space between second and fourth teeth; clypeus in profile strongly convex

O. disjuncta Tkalců

9. Mandible with third tooth symmetrically triangular, broadly separated from both fourth and second teeth by acute-angled and broad indentation; mesepisternum with hairs predominantly blackish, only on its most anterior and uppermost part with narrow zone yellowish-brown; T2 with marginal zone not impressed, with punctures of disc basomedially finer, separated by up to three puncture diameters

O. svenssoni Tkalců Mandible with third tooth asymmetrically triangular, separated from second tooth by acute-angled and broad indentation, from fourth by shallow and rounded indentation; mesepisternum with hairs uniformly white to yellowish-white, sometimes with few intermixed blackish hairs; T2 with marginal zone impressed on its entire width, with punctures of disc basomedially coarser, separated by up to two puncture diameters

O. steinmanni Müller

10. Distance between lateral ocellus and preoccipital margin two ocellar diameters; T2 and T3 with relatively well-defined, completely impunctate apical margin; integument with slight blue metallic sheen (especially on head and metasomal terga).

O. parietina Curtis

- $\quad$ Distance between lateral ocellus and preoccipital margin three ocellar diameters; T2 and T3 with relatively broad apical margins with sparse, unevenly scattered punctures; integument lacking any metallic sheen 
11. Galea with short, completely straight hairs; mesepisternum with white to pale yellow hairs; T2 with hairs in the center of disc shorter (ca. 400 micrometers); T1 only with hairs strongly yellow-brown....

- $\quad$ Galea with much longer, incurved setae; mesepisternum with blackish hairs posteroventrally; T2 with hairs in the center of disc longer (ca. 560 micrometers); T1 and T2 with hairs strongly yellow-brown (T2 at the apical edge usually with weak admixture of black hair)

O. pilicornis Smith

12. Clypeus in profile more convex, with punctures near base and in paraocular area relatively large and shallow (punctures basolaterally on clypeus distinctly larger than punctures basomedially on clypeus); forebasitarsal segment relatively long and thin (length ca. 3.5 times longer than width), length slightly longer than foretarsal segments two to five.

O. uncinata Gerstäcker

- Clypeus in profile less convex, with punctures near base and in paraocular area relatively small and deep (punctures basolaterally on clypeus the same size as those basomedially on clypeus); forebasitarsal segment relatively short and thick (length less than 3.0 times longer than width), length slightly shorter than foretarsal segments two to five.

O. laticeps Thomson

\section{Key to Eastern Hemisphere Males of Osmia (Melanosmia)}

[Modified from Tkalců 1983, 1995; Haeseler 1999; and Müller 2002. Species absent from keys in the treatments cited above and for which we have seen no specimens are excluded: O. ephippiata, O. ishikawai, O. jilinensis, O. melanota, O. nigroscopula, O. pamirensis, O. recta, and O. thoracica. (See Table 1).]

1. T5 and T6 with apicolateral angles strongly reflexed laterally O. nigriventris (Zetterstedt)

- $\quad$ T5 and T6 with apicolateral angles not or only weakly reflexed laterally .....2

2. Outer margin of gonoforceps preapically with semicircular widening, at this point gonoforceps appearing nearly twice as broad as its narrowest width; body length at least $11 \mathrm{~mm}$ [xanthomelana species group]

- $\quad$ Outer margin of gonoforceps preapically not or only weakly widened, at this point gonoforceps at most little broader than at its narrowest width; body length under $10 \mathrm{~mm}$ [inermis species group]

3. Flagellar segments on ventral surface with long, sparse hairs, their length about half the flagellar segment width; gonoforceps with apical tip (apical to juncture with preapical swelling) relatively flattened in lateral view

- $\quad$ Flagellar segments on ventral surface with hairs microscopic; gonoforceps with apical tip (apical to juncture with preapical swelling) tapering to a point and not so distinctly flattened in lateral view ........ xanthomelana (Kirby)

4. Gonoforceps with apical tip (apical to juncture with preapical swelling) enlarged on inner margin, concave and spoon-like in dorsal view; S2 with 
midapical edge weakly emarginate; $S 6$ with median truncation moderately emarginate; hind basitarsal segment relatively narrow .... O. maritima Friese Gonoforceps with apical tip (apical to juncture with preapical swelling) more or less parallel along length, not so distinctly concave in dorsal view; S2 with midapical margin not emarginate; $\mathrm{S} 6$ with median truncation evenly rounded, not emarginate; hind basitarsal segment relatively broad

O. alticola Benoist

5. S4 with midapical hairs unmodified, without hooked bristles 6 S4 with hooked bristles both along apical margin and on premarginal area, along apical margin the bristles oriented horizontally and on premarginal area directed increasingly vertically

6. S4 with apical margin clearly forming two lobes; declining basal portion of T1 densely shagreened, only with a silky luster ...... O. inermis (Zetterstedt)

- $\quad$ S4 with apical margin evenly convex; declining basal portion of T1 shining, at most superficially shagreened in small areas..... O. laticeps Thomson

7. Flagellar segments on ventral surface with conspicuous bristles with length $0.2-1.0$ times width of flagellar segment ................................................. 8

- $\quad$ Flagellar segments on ventral surface with hairs microscopic......................10

8. Flagellar segments with bristles on the undersurface as long as the flagellar segment width; S6 with median truncation narrow, distally covered with knobbed hairs

O. pilicornis Smith

- $\quad$ Flagellar segments with bristles on the undersurface only 0.2 times flagellar segment width; S6 with median truncation relatively broad, without knobbed hairs

9. Vertex of head in frontal view relatively strongly ascending, with outline of head thus more quadrangular; T2-T4 with marginal zone weakly impressed, densely shagreened at least on basal half; T2-T4 with hairs bright yellowbrown; S3 with midapical emargination one-fifth as deep as broad; S6 with midapical truncation more than one-half as long as broad; gonoforceps with outer margin preapically distinctly widened, broader than basally on gonoforceps (Fig. 69) O. svenssoni Tkalců

Vertex of head in frontal view relatively weakly ascending, with outline of head thus rounder; T2-T4 with marginal zone strongly impressed on its whole width, polished to superficially shagreened; T2-T4 with hairs yellowish-white; S3 with midapical emargination one-third as deep as broad; S6 with midapical truncation less than one-half as long as broad; gonoforceps with outer margin preapically not widened, about as broad at this point as basally on gonoforceps (Fig. 66)

O. steinmanni Müller

10. Hind basitarsal segment relatively short and broad, the basal two-thirds with diverging edges; gonoforceps subapical width (at bend) about the same as portion of gonoforceps immediately basal to it O. uncinata Gerstäcker

- $\quad$ Hind basitarsal segment relatively long and slender, the basal two-thirds not diverging; gonoforceps with subapical width (at bend) slightly but distinctly broader than portion of gonoforceps immediately basal to it...... 
11. Hind basitarsal segment with tooth positioned a third from apical margin (measured along length of segment); integument with very clear greenishblue metallic tinge O. parietina Curtis - $\quad$ Hind basitarsal segment with tooth positioned ca. half way along length; integument lacking metallic tinge on mesosoma and metasoma.....

O. disjuncta Tkalců

\section{Taxonomy}

\section{Osmia (Melanosmia) aquilonaria Rightmyer, Griswold, \& Arduser, sp. n.} urn:lsid:zoobank.org:act:E61F5E16-3FD3-48A3-B6A4-F7C6649DCF37

Figs 1, 2, 13-32

Diagnosis. Males of $O$. aquilonaria are most similar to the palearctic species $O$. svensso$n i$ and $O$. steinmanni, but can be differentiated from them by the shape and pilosity of S4 and gonoforceps (See Table 2). Osmia aquilonaria males can be distinguished from all other members of the inermis species group (except O. svenssoni and O. steinmanni) by the special form of the hairs on S4 (i.e., with two patches of hooked bristles both along apical margin and on premarginal area, along apical margin the bristles oriented horizontally and on premarginal area directed increasingly vertically, Figs 24, 25).

Females of $O$. aquilonaria can be distinguished from the only other nearctic member of the inermis species group, $O$. laticeps, by the more pointed third tooth and the parallel condylar and outer ridges of the mandible (Figs 1, 2; O. laticeps with third tooth forming cutting edge extending from fourth tooth, and with apically converging condylar and outer ridges, Figs 5, 6). Females of $O$. aquilonaria are extremely similar to those of the palearctic $O$. svenssoni, and are not readily differentiated from them other than by their respective geographic distributions.

Description. Female. Figs 1, 2, 13-18. Total length: 8.2-11.0 mm; forewing length: $6.4-6.8 \mathrm{~mm}$; length of lateral ocellus to preoccipital margin $0.7 \mathrm{~mm}$; length of lateral ocellus to compound eye $0.6-0.7 \mathrm{~mm}$.

Color: Dark brown to brown-black, sometimes with reddish overtones especially on mouthparts, labrum, mandible, flagellar segments, legs, and apical margins of T1T5. Wings mostly clear to weakly infuscate, except strongly infuscate along leading edge of forewing, especially along dorsal half of marginal cell.

Pubescence: Clypeus below apical margin with lateral tuft of golden, medially directed hairs. Dark brown, minutely branched hairs on most of body except as follows: pale golden to white, minutely branched hairs interspersed with brown on interantennal area, vertex, posterior surface of propodeum excluding triangle, and dorsal surfaces of T1, T2, T6; almost entirely pale golden to white, minutely branched hairs on mesoscutum, mesoscutellum, and metanotum; dark-brown, simple hairs interspersed with minutely branched hairs on most of body, except simple hairs lacking on dorsal 


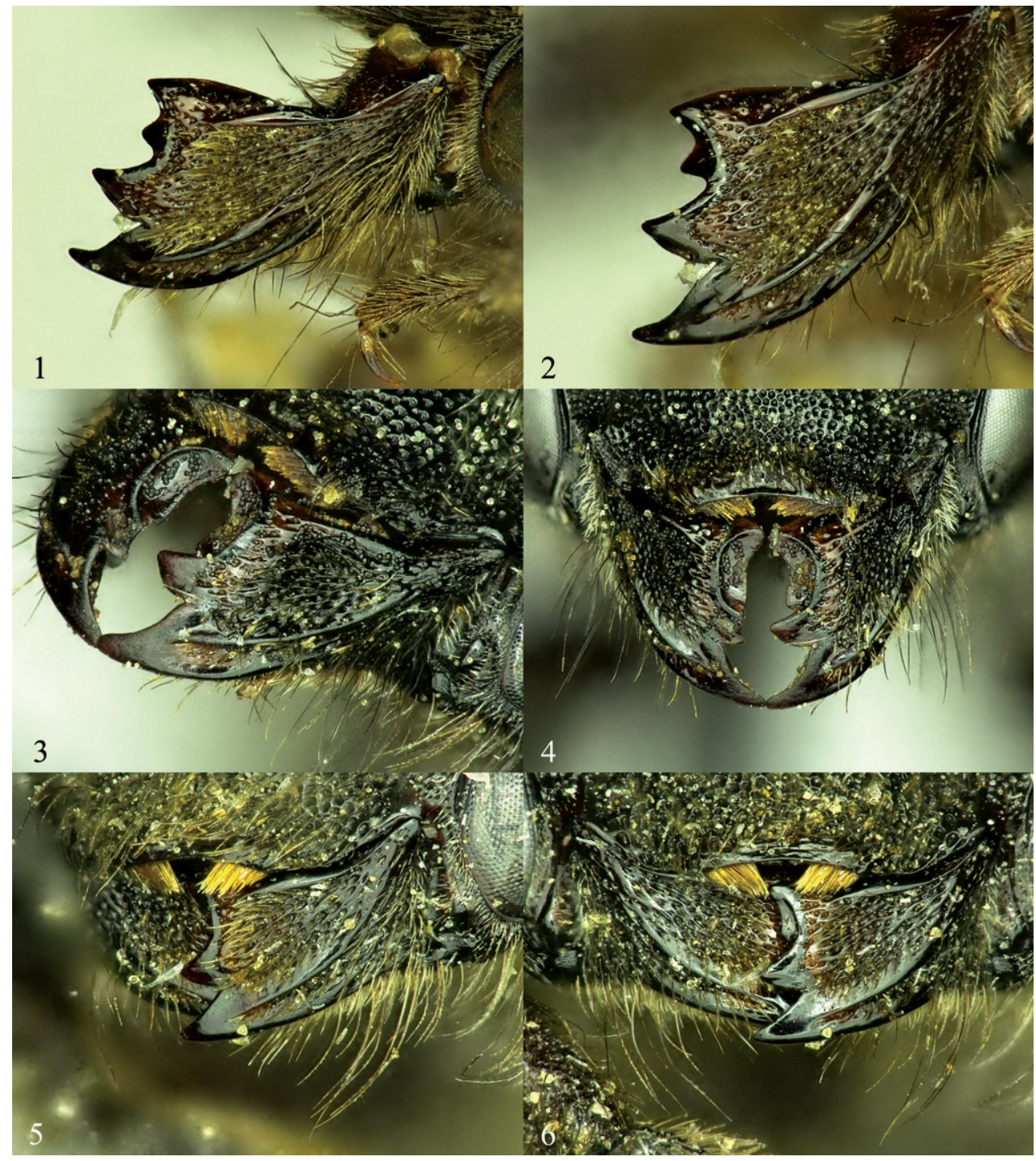

Figures I-6. Mandibles of female Osmia, left column showing the outer and condylar ridges and overall shape of mandible, right column showing shape and placement of mandibular teeth. I, 2 Osmia aquilonaria 3, 4 Osmia inermis 5, 6 Osmia laticeps.

mesosoma; dark-brown, simple hairs only (no branched hairs) on all tarsi and scopa; brown, short, simple hairs evenly covering forewing. Galea and basal two labial palpal segments with hairs on lateral margins straight, $0.2-0.5 \mathrm{OD}$ in length. Labrum with long hairs arranged in two curved, transverse rows, along subapical margin and approximately at midpoint, with additional fringe of shorter hairs at apical margin. Clypeus with hairs about as dense as on frons. Hypostomal area with hairs evenly distributed across area, straight to slightly wavy at apical tips, 2.5-4.0 OD in length. 
Table 2. Differentiating characters of male Osmia svenssoni, O. steinmanni, and O. aquilonaria.

\begin{tabular}{|c|c|c|c|}
\hline & O. svenssoni & O. steinmanni & O. aquilonaria \\
\hline gonoforceps & $\begin{array}{l}\text { Fig. 69; apically } \\
\text { evenly tapering, short; } \\
\text { preapically with outer } \\
\text { margin widened, broader } \\
\text { than basally; basally } \\
\text { swollen in lateral view; } \\
\text { hairs on preapical angle } \\
\text { mostly on dorsal surface, } \\
\text { relatively sparse }\end{array}$ & $\begin{array}{l}\text { Fig. 66; preapically not } \\
\text { widened, about as broad } \\
\text { as basally; not swollen in } \\
\text { ventral or lateral view; } \\
\text { hairs on preapical angle } \\
\text { mostly on dorsal surface, } \\
\text { moderately dense }\end{array}$ & $\begin{array}{l}\text { Fig. 26; apically long and } \\
\text { slender, preapically not } \\
\text { swollen in ventral view; } \\
\text { basally swollen in lateral } \\
\text { view; hairs on preapical } \\
\text { angle mostly on lateral } \\
\text { surface, relatively dense }\end{array}$ \\
\hline S4 & $\begin{array}{l}\text { Fig. 70; narrower gap } \\
\text { between brushes of hairs; } \\
\text { brushes of hairs densely } \\
\text { setose }\end{array}$ & $\begin{array}{l}\text { Fig. 67; wider gap } \\
\text { between brushes of hairs; } \\
\text { brushes of hairs sparser }\end{array}$ & $\begin{array}{l}\text { Figs 24, 25; wider gap } \\
\text { between brushes of hairs, } \\
\text { brushes of hairs densely } \\
\text { setose }\end{array}$ \\
\hline propodeal triangle & entirely granulose & lower two-thirds shining & Fig. 21; entirely granulose \\
\hline head & quadrate in outline & round in outline & $\begin{array}{l}\text { Fig. 20; semi-quadrate in } \\
\text { outline }\end{array}$ \\
\hline $\begin{array}{l}\text { hind basitarsal } \\
\text { segment, tooth } \\
\text { placement } \\
\text { (measured along } \\
\text { length, from } \\
\text { apical margin to } \\
\text { basal margin) }\end{array}$ & $\begin{array}{l}\text { one-fourth to one-fifth } \\
\text { from apical margin }\end{array}$ & $\begin{array}{l}\text { one-third from apical } \\
\text { margin }\end{array}$ & $\begin{array}{l}\text { Fig. 22; one-third to one- } \\
\text { fourth from apical margin } \\
\text { (shorter and broader than } \\
\text { in O. svenssoni) }\end{array}$ \\
\hline
\end{tabular}

Punctation: Head and mesosoma with punctures nearly contiguous, more or less round, and moderately impressed except as follows: labrum mostly impunctate; clypeus with impunctate midapical truncation about length of F2 or little longer (Fig. 15); mesoscutum immediately posterior to median longitudinal sulcus with punctures separated by up to two puncture diameters; mesepisternum with punctures separated by about half a puncture diameter; hypostomal area, pronotum, and legs with punctures shallowly impressed, sometimes elongated into oval shape; tegula with punctures minute, sparse medially and posteriorly, separated by up to four or five puncture diameters; metepisternum, metanotum, and lateral and posterior surfaces of propodeum with punctures very weakly impressed, with background integument strongly granulose, dull; propodeal triangle with dorsal fourth finely areolate to lineate, lower three fourths strongly granulose, dull (Fig. 16). T1 anterior and dorsal surfaces, and T2-T5 strongly shagreened, dull, with small, sparse punctures throughout except for apical margins, these punctures with integument anterior to them slightly raised, papillate; T1-T5 apical impunctate bands with length at midpoint about 4.0-6.0 puncture diameters or little more (Figs 17, 18).

Structure: Labial palpus four-segmented, second labial palpal segment ca. onethird longer than basal-most segment. Mandible with outer and condylar ridges of subequal thickness, parallel along length to very weakly converging apically (Fig. 1); apical margin with four strongly pointed teeth, third separated from second and 


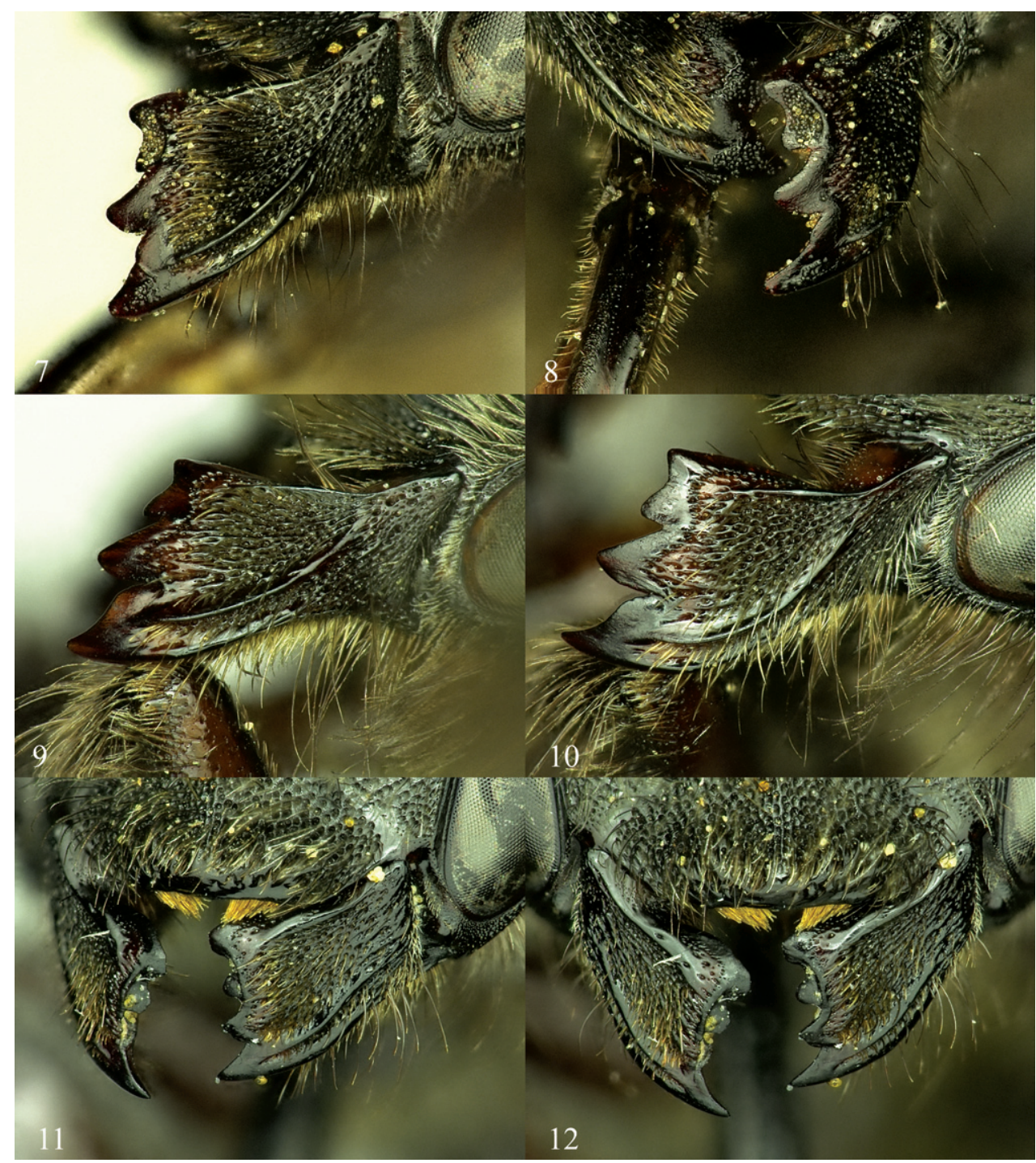

Figures 7-12. Mandibles of female Osmia, left column showing the outer and condylar ridges and overall shape of mandible, right column showing shape and placement of mandibular teeth. 7, 8 Osmia maritima 9, 10 Osmia nearctica I I, I 2 Osmia nigriventris.

fourth by carina, margin of third tooth forming distinct V-shape with adjacent margin of second and slightly smaller $V$-shape with adjacent margin of fourth, third tooth set back from second and fourth, very slightly directed inwards (Fig. 2); inner, ventral margin of mandible lacking distinct tooth, slightly diverging away from condylar ridge basally; mandible apically widened (1.3 times wider than median width), first tooth slightly longer than other teeth, length between apical tips of second and fourth teeth slightly wider than (ca. 1.2 times) apical tips of first and second teeth (Fig. 2). 
Clypeus with apical margin linear to moderately emarginate medially, with entire apical truncation laterally more or less contiguous with remaining lateral margin of clypeus (not forming 90 degree angle with lateral apical margin of clypeus; Fig. 15). F1 twice length of F2 or slightly more, remaining apical flagellar segments gradually increasing in length such that F10 subequal to F1 or little longer. Vertex behind lateral ocellus 2.5-3.0 OD in length. Genal width 1.5 to nearly 2.0 times that of compound eye in lateral view. Preoccipital margin rounded, not carinate. Hypostomal carina moderately high, highest at about midpoint of hypostomal area posterior to angle and sometimes forming moderate triangular projection at this point, tapering to low carina or near obsolescence at angle. Malus forming pointed apical spine, this spine more or less a continuation of nearby edge of vellum. Foretarsal segments excluding basitarsal and apical-most segments with anterior lobes slightly longer than posterior. Midtarsal segments with anterior and posterior lobes of equal width, slightly swollen; hind tarsal segments not swollen. Hind tibial spurs strongly curved at apical tips, outer spur about one fifth shorter than inner. Hind basitarsal segment with lateral margins of outer surface parallel.

Male. Figs 19-32. Total length: $9.5 \mathrm{~mm}(8.2-9.5 \mathrm{~mm})$; forewing length: $6.3 \mathrm{~mm}$ (5.9-6.3 mm); length of lateral ocellus to preoccipital margin $0.5 \mathrm{~mm}(0.4-0.5 \mathrm{~mm})$; length of lateral ocellus to compound eye $0.5 \mathrm{~mm}$.

Color: Black to dark brown, sometimes with reddish overtones especially on mouthparts, labrum, mandible, flagellar segments, legs, and apical margins of T1-T6 and S1-S3. Wings mostly clear except weakly infuscate along leading edge of forewing, especially along dorsal half of marginal cell.

Pubescence: White to golden, minutely branched hairs on body except golden to pale golden, stouter hairs on inner surfaces of tarsi, S4, and S6. Labrum covered with hairs on apical third and with hairs forming short fringe at apical margin. S2 with hairs at apical third relatively long (ca. 3.0 OD). S3 with dense, medially directed hairs filling entire emargination (hairs ca. 1.0 OD in length medially, nearly $2.0 \mathrm{OD}$ laterally) (Fig. 24). $\$ 4$ midapical truncation with two patches of dense, golden, distally hooked hairs, these patches of hairs medially interrupted by nearly $1.0 \mathrm{OD}$, with hairs distally meeting at midpoint, each patch along apical margin with hairs oriented horizontally and on premarginal area directed increasingly vertically (Figs 24, 25). S6 midapical truncation sparsely covered with short, distally hooked hairs arising from papillate bases (Fig. 28).

Punctation: Head with punctures ovate to nearly circular, separated by one-fourth to one-half puncture diameter and deeply impressed except as follows: labrum mostly impunctate on basal two-thirds; clypeus with impunctate band along apical margin, about one-third length of $\mathrm{F} 1$ in length; disc of clypeus, interantennal area, and paraocular area with punctures small, ovate, and nearly contiguous (punctures mostly obscured beneath dense hairs); hypostomal area anteriorly near angle with punctures weakly, shallowly impressed. Mesosoma with punctures more or less round, nearly contiguous to separated by up to a half puncture diameter, deeply impressed except as follows: mesoscutum immediately posterior to median longitudinal sulcus with punc- 


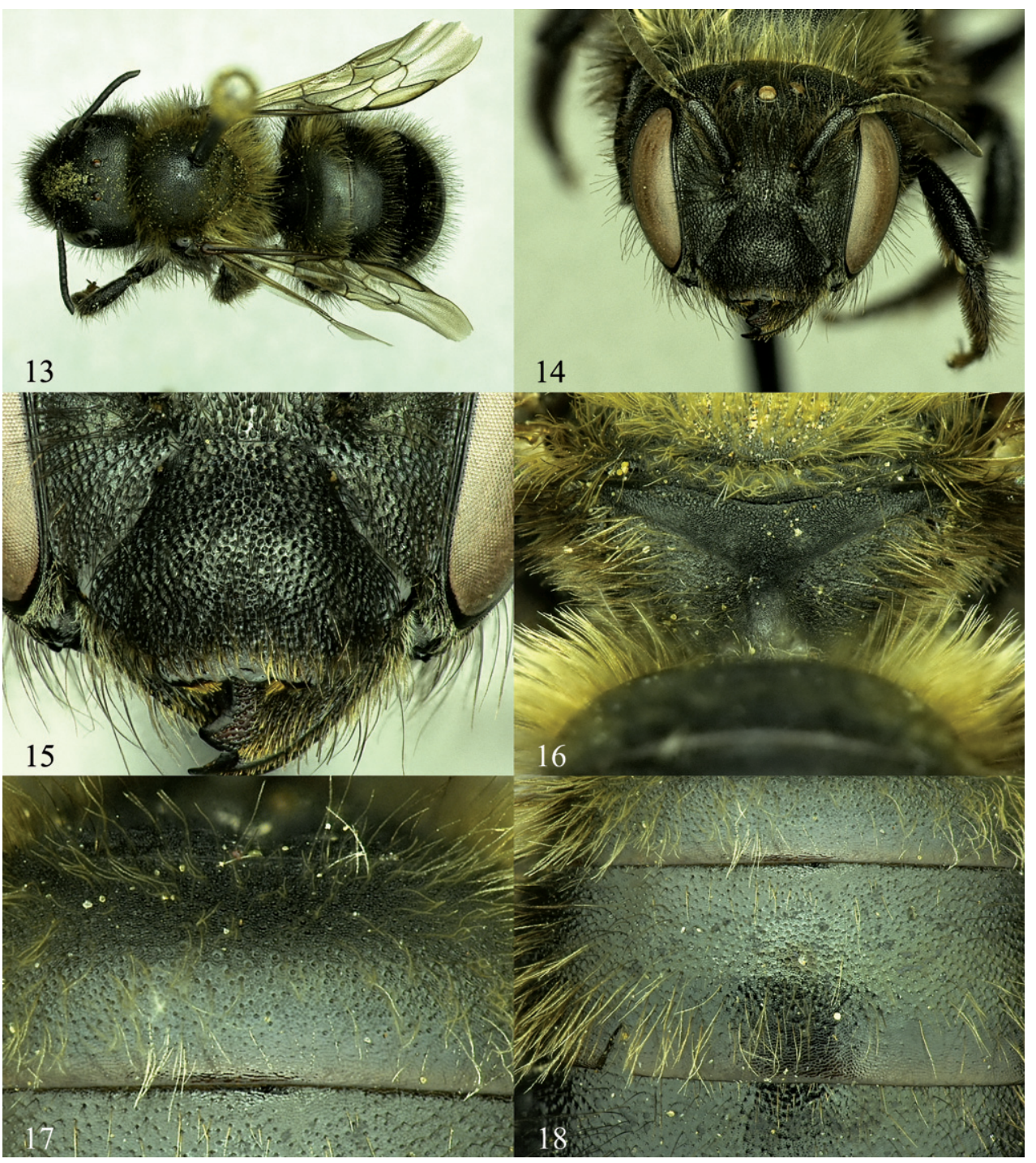

Figures 13-18. Osmia aquilonaria, female paratypes. I 3 Dorsal habitus 14 Face 15 Clypeus $\mathbf{1 6}$ Posterior surface of propodeum and propodeal triangle $\mathbf{1 7} \mathrm{T} 1$ and basal area of $\mathrm{T} 2$, showing surface sculpturing 18 Apical area of T1, T2, and basal area of T3.

tures separated by up to one, sometimes as much as three puncture diameters; tegula with punctures minute, sparse medially, separated by up to eight to ten puncture diameters; pronotum, metepisternum and lateral and posterior surface of propodeum strongly shagreened, with weakly, shallowly impressed, larger punctures; metanotum and propodeal triangle strongly granulose, dull (Fig. 21); propodeal triangle lineolate on dorsal fifth; legs with inner surfaces of trochanters, femora, and tibiae shining, with scattered smaller punctures. T1 with anterior surface strongly shagreened, dull; 
metasomal terga with dorsal surfaces excluding apical margins strongly shagreened, apical impunctate margins moderately to weakly shagreened (except T7 moderately polished). T1 dorsal surface with punctures minute, moderately distinct and wellimpressed, separated from 1.0 to 3.0 puncture diameters; apical impunctate margin medially ca. 10.0 puncture diameters in length, laterally as little as 6.0 puncture diameters. T2-T7 with punctures minute, T2 with punctures separated by ca. 1.0 puncture diameter medially (sparser towards impunctate apical margin on all terga), successively posterior terga with punctures progressively becoming more widely spaced to about 3.0 puncture diameters apart on disc of T7; T2-T6 with apical impunctate margins 6.0-9.0 puncture diameters in length, T7 with apical impunctate margin 4.0-6.0 puncture diameters in length. S1-S3 with punctures weakly, shallowly impressed. S4 with integument granular, dull (Fig. 24). S5-S6 lacking distinct punctures, weakly shagreened.

Structure: Mandible with outer and condylar ridges converging apically; apical margin with two teeth, upper tooth distinctly shorter and slightly wider than lower, upper tooth with inner and dorsal margins forming ca. 70-80 degree angle; inner, ventral margin of mandible weakly diverging away from condylar ridge basally. $\mathrm{Cl}-$ ypeus apical margin with irregular tubercles, lacking distinct apical truncation. Flagellar segments subequal in length, except F1 about three-fourths length of F2 and F11 slightly longer than other segments. Vertex behind lateral ocellus $2.0 \mathrm{OD}$ in length or nearly so. Genal width subequal that of compound eye in lateral view (slightly wider dorsally). Preoccipital margin rounded, not carinate. Hypostomal carina moderately high, gradually tapering to near obsolescence at angle, not forming distinct tooth. Malus forming small but distinct apical spine. Foretarsal segments excluding basitarsal and apical-most segments with lobes slightly, equally swollen. Mid- and hind tarsal segments not swollen. Hind tibial spurs curved at apical fifth, outer spur slightly shorter than inner. Hind basitarsal segment with lateral margins of outer surface weakly diverging apically, with strong tooth on inner margin (Fig. 22). T6 midapically with small but usually distinct emargination, forming ca. one-fourth to one-half of circle in outline (Fig. 23); T6 lateroapical margin smoothly, weakly convex, not forming distinct tooth. T7 midapically strongly emarginate, forming semicircle about as wide as deep (ca. 0.5-0.8 OD wide), with spines on either side of emargination weakly pointed, basally nearly as wide as emargination width (Fig. 23). S2 evenly convex, covering most of S3. S3 with midapical emargination relatively wide and shallow (half entire width of sternum, 1.0 OD in length, measuring only apical margin of sternum and not including basal fringe of hairs; Fig. 24). $\$ 4$ midapically with wide truncation (about half width of entire sternum), medially with shallow but distinct emargination between lateral tufts of hairs (Fig. 24). S5 with apical margin evenly, strongly concave along median half of margin. S6 with strong midapical truncation, slightly less than one-third width of sternum, truncation slightly wider than deep, apical margin of truncation weakly, evenly rounded apically, sometimes with small emargination medially (Fig. 28). S8 as in Fig. 29. Gonoforceps weakly narrowed apical to subapical bend in dorsal, ventral, and lateral views (Figs 26, 27, 30-32). 


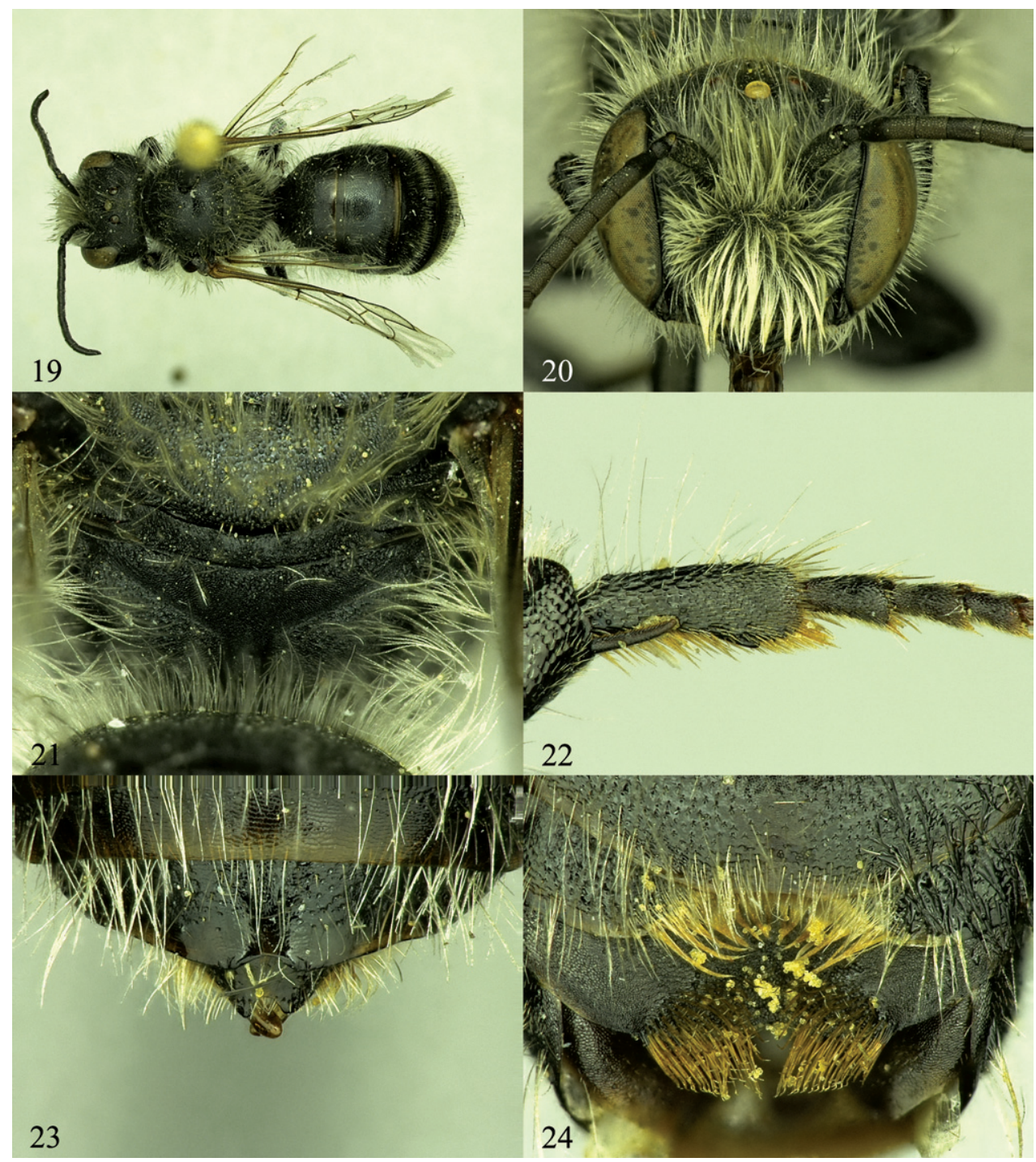

Figures 19-24. Osmia aquilonaria, male holotype. 19 Dorsal habitus 20 Face $\mathbf{2}$ I Posterior surface of propodeum and propodeal triangle $\mathbf{2 2}$ Hind basitarsal segment, showing inner tooth $\mathbf{2 3}$ T5-T7 and apical tip of gonoforceps 24 S2-S4.

Distribution. Alaska and Northwest Territories south to Wyoming, and east across Canada to Nova Scotia.

Holotype male. "[Canada] N.W.T. [Northwest Territories] km 491, Dempster Hwy, 26.VI.80 [26 June 1980], $1000 \mathrm{~m}$, Wood \& Lafontaine//Osmia svenssoni Tkalcu ¿ T Griswold det 96// Holotype male Osmia aquilonaria Rightmyer, Griswold, \& Arduser" (Отташа) 
Paratypes. CANADA: NORTHWEST TERRITORIES, Inuvik Region, Aklavik, 25 June 1931, O. Bryant (1 $q$, Logan), 25 July 1931, $1600 \mathrm{ft}$ (1 $q$, San FrancisCo); Black Mountain, SW of Aklavik, 1 August 1931, O. Bryant (1ㅇ, 1ð, Logan); Holman, Victoria Island, 25 June 1952, B. A. Gibbard (1우, OtтAWA); NOVA SCOTIA, Cape Breton Highlands National Park, 60 $50^{\prime} \mathrm{W} 46^{\circ} 47^{\prime} \mathrm{N}$, 22 June 1983, Birch (1 9 , Отtawa); NUNAVUT, Kitikmeot Region, Coppermine, 3 August 1951, S. D. Hicks (19, OtтAWA); ONTARIO, Cochrane District, Low Bush, Lake Abitibi, 5 June 1925, N. K. Bigelow (19, Sт. Charles), 18 June 1925, N. K. Bigelow (1ㅇ, ST. Charles); Thunder Bay District, Silver Island, Sibley Peninsula, 18 July 1961, Rubus sp., H. E. Milliron (1 + , Оттаwa); QUEBEC, Nord-du-Québec Region, Highway

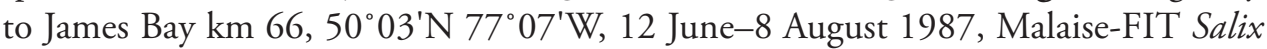
bushes, L. Leblanc (19, Оттаwa); YUKON, Dempster Highway km 465, 23-25 June 1980, 800 m, Wood \& Lafontaine (2q, ОттаWA); USA: ALASKA, North Slope Borough, Cape Thompson, 29 June 1961, B. S. Heming (1웅 ОттаWA); YukonKoyukuk Census Area, Kathul Mountain, Yukon River, Steppe, 4 June 1991, Arnica alpina, J. A. Bishop (1ㅇ, Davis), 5 June 1991, Lupinus arcticus (1ㅇ, DAvIs); Kathul Mountain, Yukon River, 110 km NW Eagle, Tundra, 16 June 1992, Lupinus arcticus, J. A. Bishop (1 9 , Davis); WYOMING, Fremont Co., Roaring Fork Mountain, Wind River Range, 29 June 1990, 11000-1200 ft, E. A. Sugden (6ㅇ, 3خ̂, Logan).

Etymology. The name "aquilonaria" is Latin, meaning northern or northerly, and is in reference to the northern distribution of the species in North America.

\section{Osmia (Melanosmia) inermis (Zetterstedt)}

Figs 3, 4, 52, 56, 60

Anthophora (Osmia) inermis Zetterstedt 1838: 466 [Lectotype male: Lund]; Tkalců 1983: 153 [Lectotype designation].

Osmia globosa Cresson 1864: 36 [Holotype female: Philadelphia]; Sandhouse 1939:

34 [synonymy]; Ungricht et al. 2008: 166 [preoccupied name, not Apis globosa Scopoli 1763].

Osmia vulpecula Gerstäcker 1869: 335 [Lectotype female: Berlin]; Thomson 1872: 244 [synonymy]; Tkalců 1983: 153 [Lectotype designation]

Osmia globosiformis Cockerell 1910: 311 [Holotype male: San Francisco]; Sandhouse 1939: 34 [synonymy].

Osmia (Melanosmia) inermis (Zetterstedt); Friese 1911: 122; Sandhouse 1939: 34-35 [redescription of male and female].

Osmia (Chenosmia) inermis (Zetterstedt); Sinha 1958: 235.

Diagnosis. Females are known by the slightly acute angle or tooth midway on the ventral margin of the mandible (Fig. 52). Males can be distinguished by the form of the S4, which is strongly truncate and emarginate medially, forming distinct, rounded sublateral lobes (Fig. 60). 


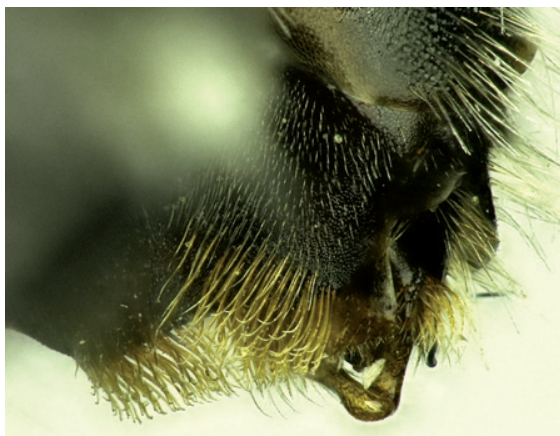

25
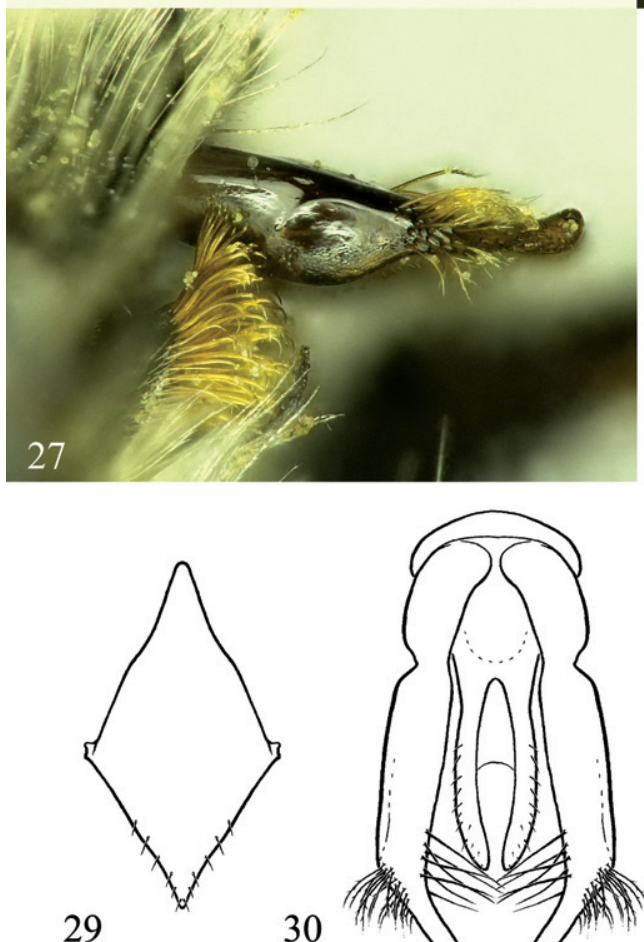

30
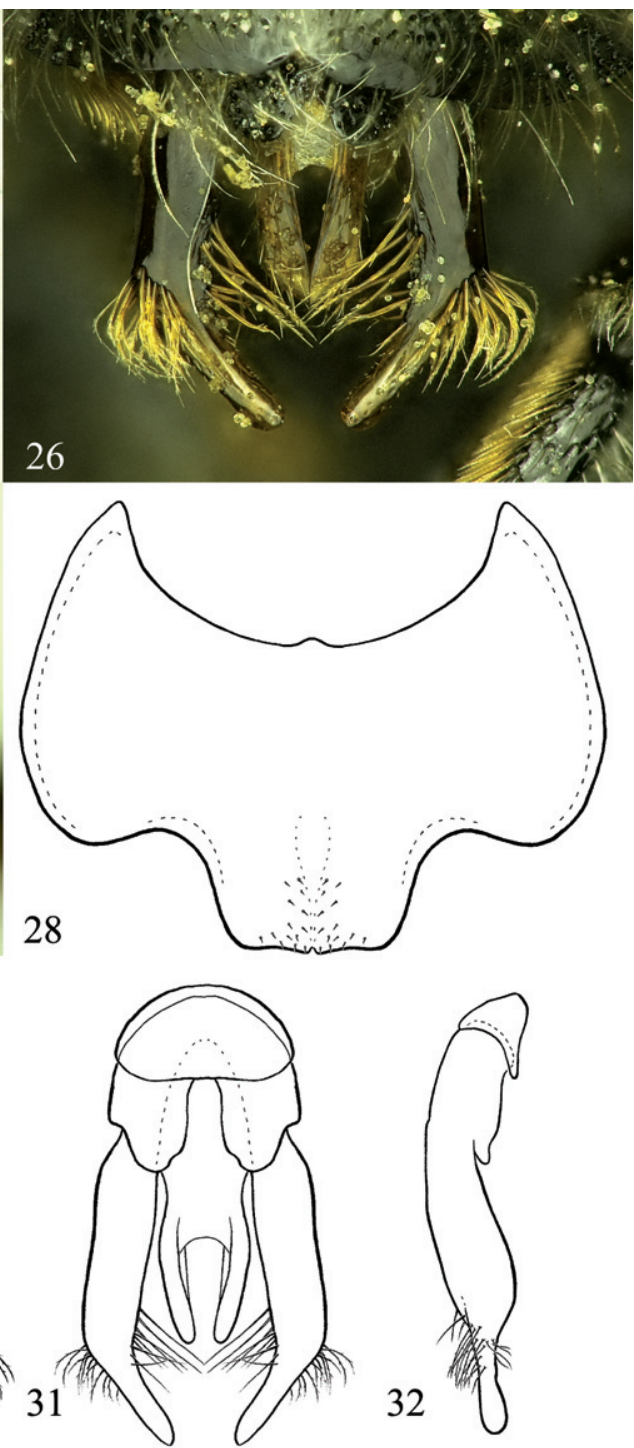

Figures 25-32. Osmia aquilonaria, male holotype and paratype. 25 Oblique view of S4 26 Dorsal view of genital capsule $\mathbf{2 7}$ Lateral view of gonoforceps and S4 $\mathbf{2 8}$ Ventral view of S6 29 Ventral view of S8 30 Dorsal view of genital capsule 31 Ventral view of genital capsule 32 Lateral view of genital capsule, excluding penis valve.

Distribution. In the Nearctic, from Sierra Nevada of California north to British Columbia and Alaska, east through Canada to Nova Scotia and Newfoundland south in the United States to Massachusetts, Michigan, the Black Hills of South Dakota, and mountainous areas of Nevada, Utah, and Colorado. In the Palearctic, O. inermis is found from Spain, Italy, and Greece north to the United Kingdom, Norway, Sweden, 
and Finland, and east through Russia and northern China (Müller, 2010). The related, if not synonymous, species $O$. ishikawai is found in Japan.

Comments. Osmia inermis has been recorded nesting under stone or in preexisting cavities in rocks and stones, with cells composed of chewed leaves (Lovell 1909; Müller 2010 and references therein). In the Palearctic, O. inermis is polylectic with a preference for Fabaceae (Müller 2010 and references therein); however, in Newfoundland, Canada, the species has been shown to be primarily dependent upon Ericaceae (Hicks 2009).

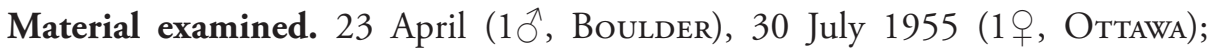

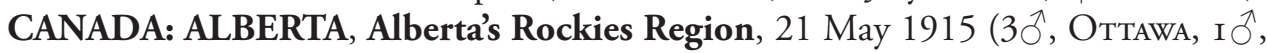

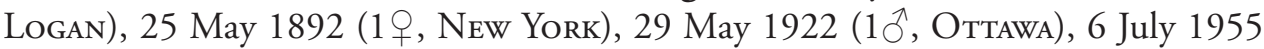
(1우, Ottawa); Northern Alberta Region, 29 May 1977 (1우, Logan); BRITISH COLUMBIA, Central Kootenay, 3 June 1906 (1 9 , OtтаWA), 9 June (1 9 , BoulDER); Stikine Region, 6 June 1955, 2200 ft (1今, OtтAWA), 17 June 1955, 2200 $\mathrm{ft}$ (1우, ОттаWA); Okanagan-Similkameen District, 21 May 1958 (10․ ОттаWA); MANITOBA, Northern Region, 1 July 1927 (1우, Otтawa), 11 July 1950 (1우, Отtawa), 29 July 1949 (1우, Ottawa); Parkland Region, 26 June 1961, $2000 \mathrm{ft}$ (1 , OtTaWa); NEW BRUNSWICK, St. John Co., 9 June 1901 (19, Logan), 23 June

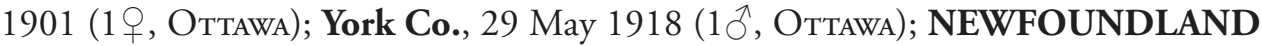
AND LABRADOR, Twillingate Islands, 30 May 1951 (13ㅇ, ОттAWA); NOVA SCOTIA, Halifax Co., 2 July 1914 (19, Otтаwa); Hants Co., 4 June 1931, Cor-

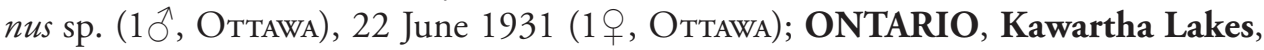

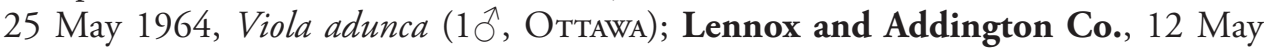
1962, Chamaedaphne sp. (1 9 , Toronto); Rainy River District, 2 July 1960 (19, Ottawa); QUEBEC, Capitale-Nationale Region, 17 May 1914 (2ㅇ, ОттаWA), 28 May 1916, Vaccinium sp. (29, OттаWA); Nord-du-Québec Region, 4-12 June 1987

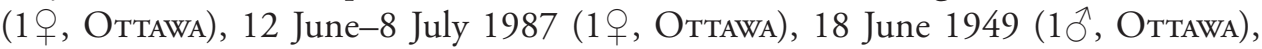
14 August 1949 (1 9 , OtтaWa), 18 August 1949 (4q, OtтaWa), 23 August 1949 (2ㅇ, Отташа), 2 September 1949 (8ㅇ, Отtawa), 3 September 1949 (1우, OtтAWA); Outaouais Region, 14 May 1916, Vaccinium sp. (1ㅇ, 1§, OtтаWA); YUKON, 26

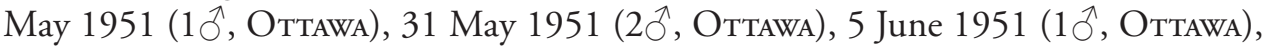
12 June 1960, $3500 \mathrm{ft}$ (19, OtтaWA), 21 June 1949, $5200 \mathrm{ft}$ (19, OtтAWA), 2 July 1962, $3500 \mathrm{ft}$ (1 9 , OтtaWa), 10 July 1985 (1우, Victoria); RUSSIA, Siberia, 3 July 1992 (1 $q$, Davis), 5 July 1992 (1 + , Davis); SWEDEN: (1 $q$, Uppsala), 12-19 June 1972 (1 9 , Uppsala), Jönköping Co., 12 July 1932 (1 9 , LogAN); Norrbotten Co.,

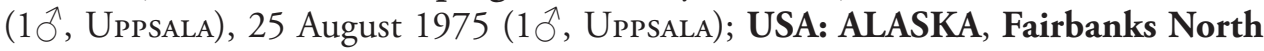
Star Borough, 19 May 1987 (1 9 , DAVIS); Kenai Peninsula, 20 June 1951 (1 + , ОтTAWA); CALIFORNIA, Madera Co., 19 July 2004, 3315 m, Phyllodoce breweri (10ิ,

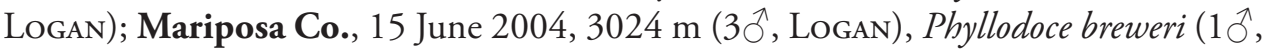
LogAN), $3215 \mathrm{~m}$ (10̂, LogAN), 23 June 2004, $3112 \mathrm{~m}$ (10̂, LogAN), 4 July 2004, $2860 \mathrm{~m}$ (1 + , Logan), $2847 \mathrm{~m}$, Horkelia tridentata (19, Logan), 14 July 2005, 3112

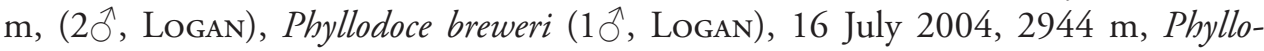
doce breweri (1 + , Logan), 14 August 2004, 3189 m, (1 $\odot$, Logan), 1 August 2005, 


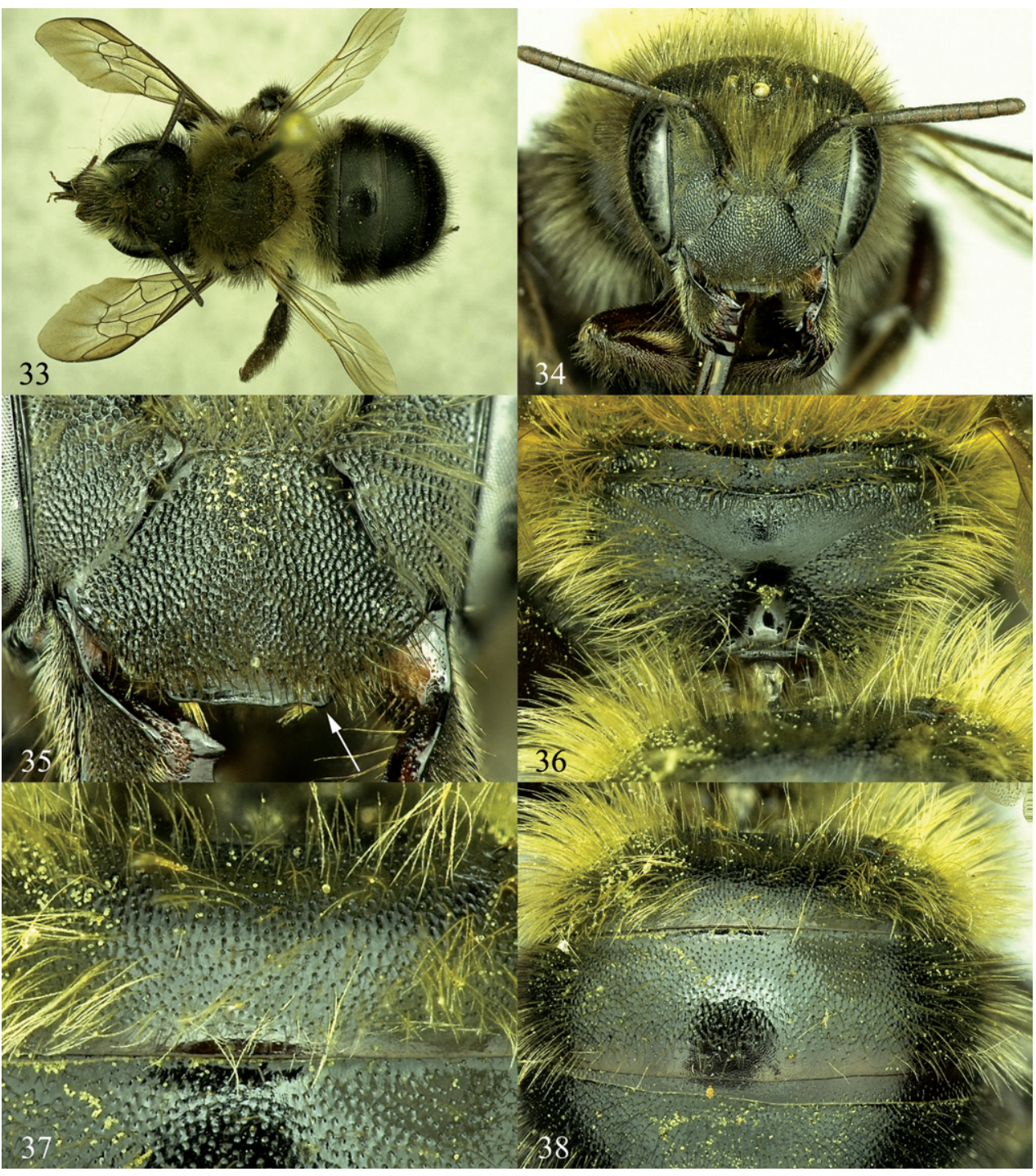

Figures 33-38. Osmia nearctica, female paratypes. $\mathbf{3 3}$ Dorsal habitus $\mathbf{3 4}$ Face $\mathbf{3 5}$ Clypeus $\mathbf{3 6}$ Posterior surface of propodeum and propodeal triangle $37 \mathrm{~T} 1$ and basal area of T2, showing surface sculpturing 38 Apical area of T1, T2, and basal area of T3.

3189 m, (10, Logan); Shasta Co., 30 July 1947, $7000 \mathrm{ft}$ (19, Logan), Tuolumne

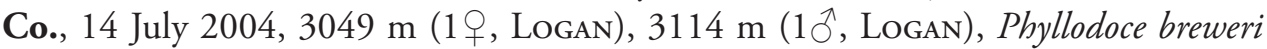
(2ㅇ, Logan), 15 July 2004, $3215 \mathrm{~m},\left(3{ }^{\lambda}\right.$, Logan), Phyllodoce breweri (1 + , Logan), 17 July 2005, 3215 m (2ð, Logan), 28 July 2006, 3215 m, Arenaria kingii var. glabrescens (1 9 , LogAN), Eriogonum incanum (1 9 , LogAN), Phyllodoce breweri (1q, Logan); COLORADO, Boulder Co., 18 June 1940 (1 9 , Boulder), 20 June 1940 (1우, Boulder), 27 June 1939 (1우, Boulder), 8 July 1940 (1우, Boulder); Grand 
Co., 22 June 1976 ( 1 , Boulder); Larimer Co., 19 June ( 1 , Boulder), 25 July (1우, Boulder); Mesa Co., 10 July 1938 (1웅, Boulder); Routt Co., 21 May 1964,

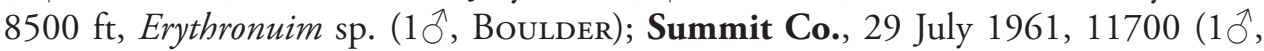
Ottawa); IDAHO, Bear Lake Co., 10 August 1972 (19, Logan); Lemhi Co., 20 July 1963 (2ᄋ, Moscow); MAINE, Knox Co., 28 May 1962, Vaccinium angustifolium (10̃, St. Charles); MASSACHUSETTS, Barnstable Co., 16 May 1914 (10๊, Logan); MICHIGAN, Alger Co., 23 May 1982, Vaccinium sp. (10̂, St. Charles), 29 May 1991, Vaccinium angustifolium (2, ST. Charles); Marquette Co., 25 May

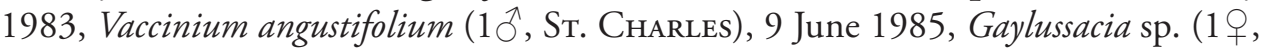
St. Charles), 21 June 1984 (1 9 , St. Charles); MONTANA, Carbon Co., 10 July 1963, $5900 \mathrm{ft}$, Melilotus sp. (69, Boulder), 12 July 1963, $5900 \mathrm{ft}$, Melilotus sp. (1 9 , Boulder), 28 July 1975 (1 9 , Boulder); Gallatin Co., 1 May 1927 (1 $\circ$, LogaN),

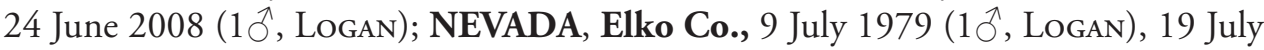
1975, $9500 \mathrm{ft}$ (1ð, Logan-TG), 21 July 1976, $9600 \mathrm{ft}$ (2ð, Logan-TG); OREGON, Baker Co., 15 July 1930, 7100 ft (19, Convaluis); Wallowa Co., 26 July 1929, $7500 \mathrm{ft}$ (1 9 , Corvallis); SOUTH DAKOTA, Custer Co., 20 June 1955, Trifolium repens (1 9 , St. Charles); UTAH, Cache Co., 7 June 1962, (1 9 , Logan), 18 June 1948, Wyethia sp (2ð, Logan), 30 June 1976, Penstemon leonardi (1 9 , Logan), 4 July 1947, Ranunculus acriformis var. montanensis (1ㅇ, 10․ LogAN), 5 July 1981, $8500 \mathrm{ft}$ (19, Logan-TG), 17 July 1995, 8200-8600 ft, Penstemon sp. (2ㅇ, Logan), 25 July 1971 (1ð, Logan), 28 July 1975, Penstemon cyananthus (1우, Logan); 1 August 1965 (1 9 , Logan), 4 August 1975, Potentilla fruticosa (1 + , Logan); Grand Co., 8 June

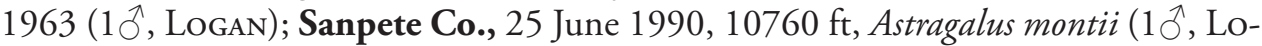

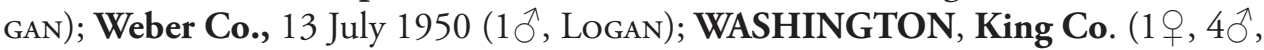
Boulder); WYOMING, Big Horn Co., 6 August 2000, 8975 ft, Machaeranthera sp. (19, Boulder); Carbon Co., 31 May 1972 (10̄, Boulder); Fremont Co., 10 June

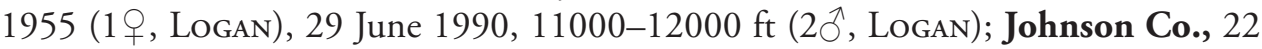
July 1998 (19, Logan); Sheridan Co., 26 June 1986 (1웅, Ottawa); Sublette Co., 20 July 1959 (2q, Logan); Teton Co., July 1937 (1 $q$, Logan), 4 July 1983, 6700 $\mathrm{ft}$, Hedysarum boreale (19, LogAN), 13 July 1983, $6700 \mathrm{ft}$, Hedysarum boreale (1우, Logan); 17 July 1983, $6700 \mathrm{ft}$, Hedysarum boreale (1 9 , Logan).

\section{Osmia (Melanosmia) laticeps Thomson}

Figs 5, 6, 54, 58, 61

Osmia laticeps Thomson 1872: 242 [Lectotype female: Lund]; Dalla Torre 1896: 414 [synonymy with $O$. uncinata Gerstäcker]; Tkalců 1983: 154 [Lectotype designation]; Nilsson 2009: 51 [rejection of synonymy with O. uncinata Gerstäcker].

Osmia (Melanosmia) hyperborea Tkalců 1983: 156 [Holotype male: Uppsala]; Schwarz et al. 1996: 126 [synonymy with O. parietina Curtis]; Haeseler 1999: 454 [rejection of synonymy with $O$. parietina Curtis, diagnosis of female]; Nilsson 2009: 52 [synonymy with $O$. laticeps Thomson]. 


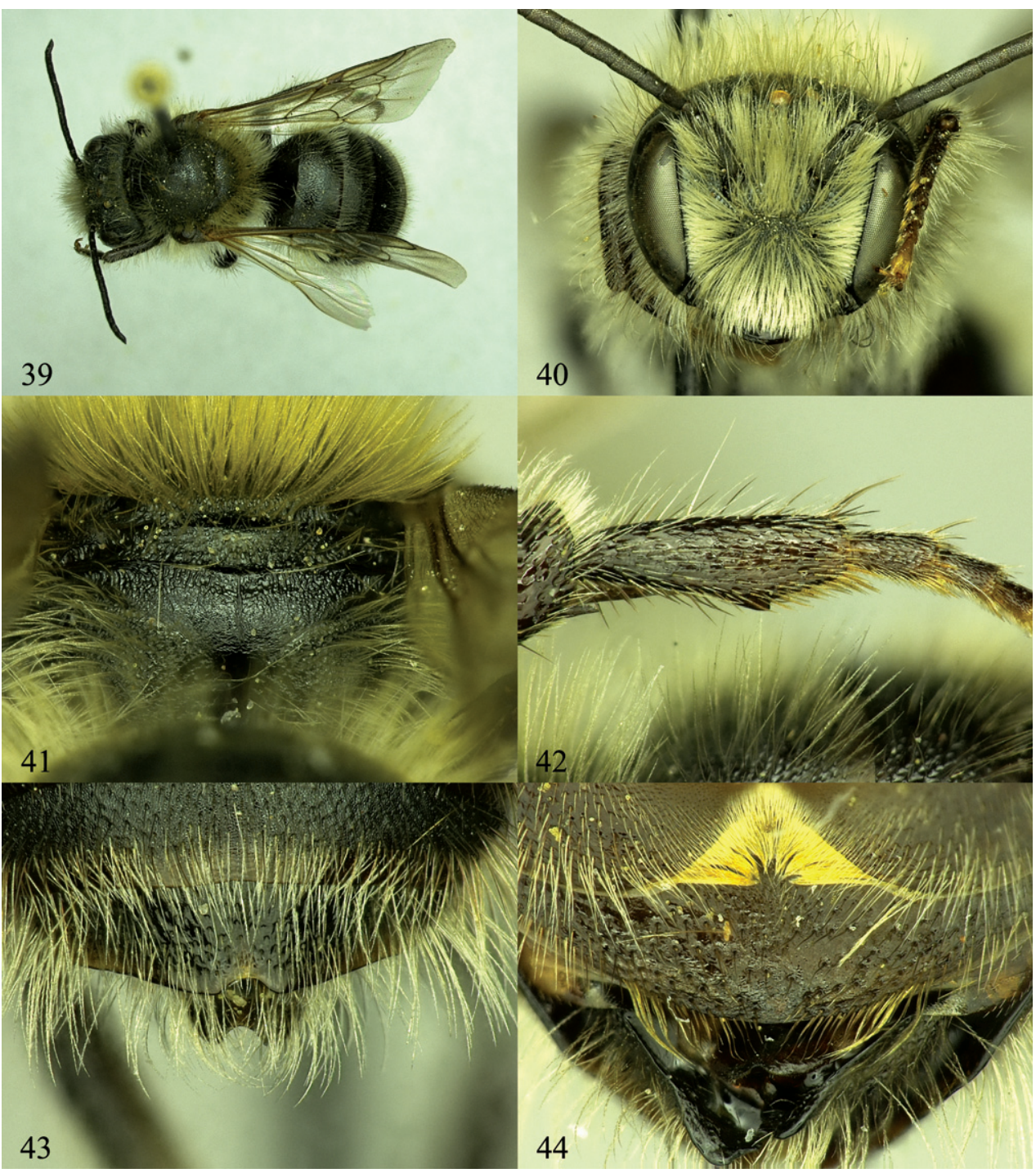

Figures 39-44. Osmia nearctica, male holotype. 39 Dorsal habitus 40 Face 41 Posterior surface of propodeum and propodeal triangle 42 Hind basitarsal segment, showing inner tooth 43 T5-T7 44 S3 and S4.

Diagnosis. Females of $O$. laticeps are distinguished from all other North American non-metallic Osmia by the following characters of the mandible (Figs 5, 6): the apical margin is only slightly broader than the median width, the third tooth is relatively broad and not strongly separated from the fourth tooth, and the condylar and outer ridges converge apically; in addition, they are diagnosed by their strongly granulose propodeal triangle and relatively short apical impunctate bands on T2 and T3. 
In the Palearctic, $O$. laticeps is most similar to $O$. uncinata. In addition to the characters mentioned in the key (above), the following characters can be used to distinguish females of the two species (most characters first noticed by Haeseler 1999): in $O$. laticeps, the clypeus has more plentiful pale hairs than black hairs, and these pale hairs are about the same length as the black hairs. In O. uncinata, the clypeus has nearly the same amount of black hairs as pale hairs, and the black hairs are distinctly longer than the pale hairs. The malus of the foretibia has the apical tip evenly tapering to a point in O. laticeps, while in O. uncinata the tip is slightly more blunt. The outer hind tibial spur is more strongly downcurved in O. uncinata than in O. laticeps. Additionally, the hairs of the hypostomal area are denser and more strongly incurved in O. laticeps than in O. uncinata.

In both the Nearctic and Palearctic, males are known by the non-swollen gonoforceps (outer margin preapically only weakly widened, about the same width as the gonoforceps basal and distal to this preapical point of inflection), and the relatively unmodified S4 (Fig. 61): the apical margin of S4 is evenly convex and midapically on $S 4$ the relatively short, unmodified hairs arise from regularly-spaced tubercles (not forming distinct, sublateral tufts of apically hooked hairs).

Description. Female. Figs 5, 6, 54, 58. Total length: 8.4-9.0 mm; forewing length: $6.0-8.1 \mathrm{~mm}$; length of lateral ocellus to preoccipital margin $0.6-0.7 \mathrm{~mm}$; length of lateral ocellus to compound eye $0.6-0.7 \mathrm{~mm}$.

Color: Dark brown to brown-black, sometimes with reddish overtones especially on mouthparts, labrum, mandible, flagellar segments, legs, and apical margins of T1T5. Wings mostly clear to weakly infuscate, except moderately infuscate along dorsal half of marginal cell.

Pubescence: Clypeus below apical margin with lateral tuft of golden, medially directed hairs. White to golden, minutely branched hairs on most of body except as follows: brown, simple hairs interspersed with pale, branched hairs on clypeus, sometimes interantennal area and near ocelli, gena ventrally and along compound eye, outer surfaces of femora and tibiae (especially on fore and midlegs); dark-brown, simple hairs only (no branched hairs) on mouthparts, labrum, inner surfaces of legs (golden on tarsi), outer surfaces of hind tibia and all tarsi, T2-T6, and scopa; brown, short, simple hairs evenly covering forewing. Galea and basal two labial palpal segments with hairs on lateral margins straight, $0.2-0.3 \mathrm{OD}$ in length. Labrum with long hairs arranged in two curved, transverse rows, along subapical margin and approximately at midpoint, with additional fringe of minute hairs at apical margin. Clypeus with hairs about as dense as on frons, midapically with some hairs slightly curved at apical tips. Hypostomal area with straight hairs evenly distributed across most of area, 2.0-3.0 OD in length.

Punctation: Head and mesosoma with punctures nearly contiguous, more or less round, and moderately impressed except as follows: labrum mostly impunctate except near fringes of hairs; clypeus with impunctate midapical truncation about length of F2 or little longer (Fig. 54); mesoscutum immediately posterior to median longitudinal sulcus with punctures separated by up to a puncture diameter; mesepisternum with punc- 

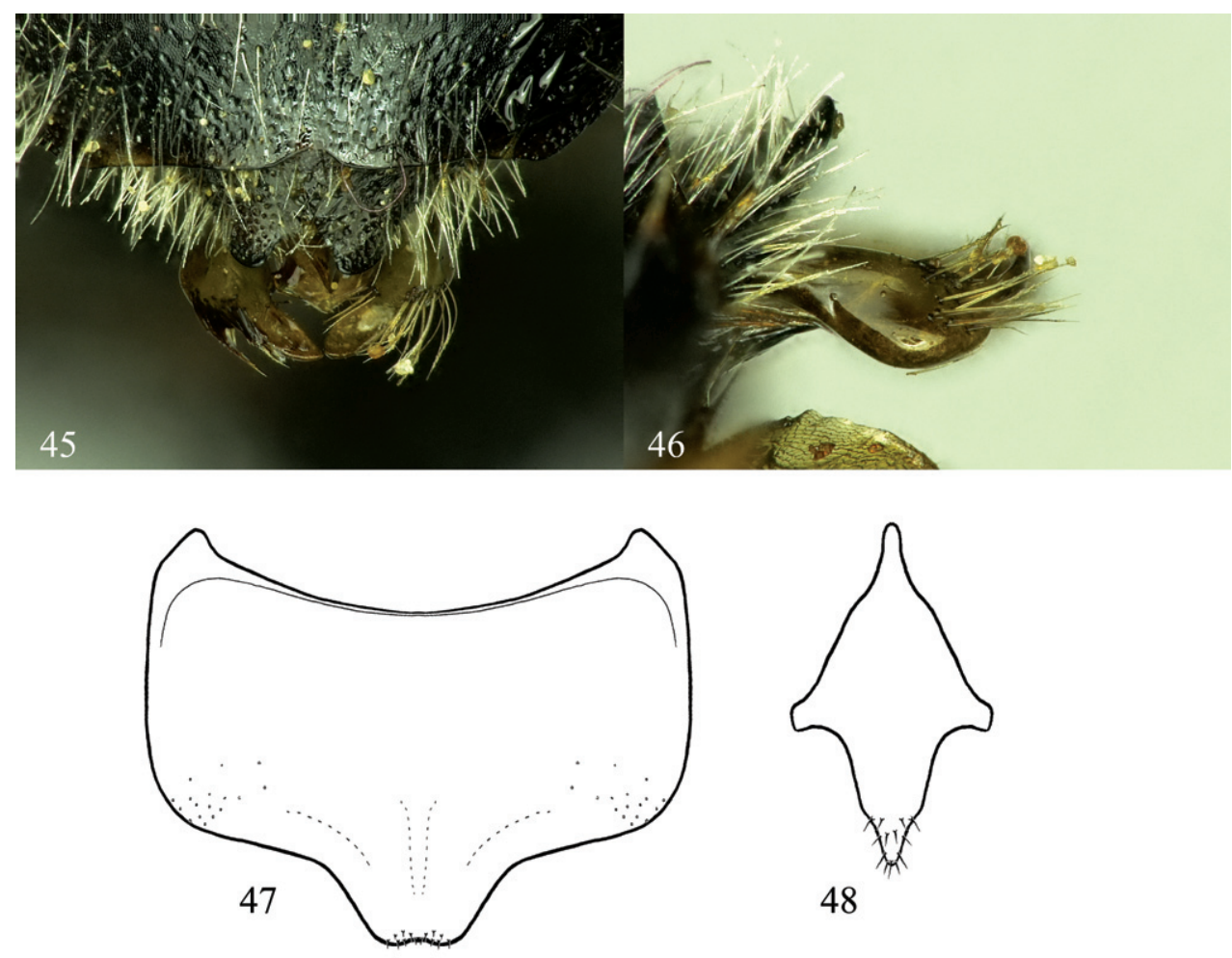

49
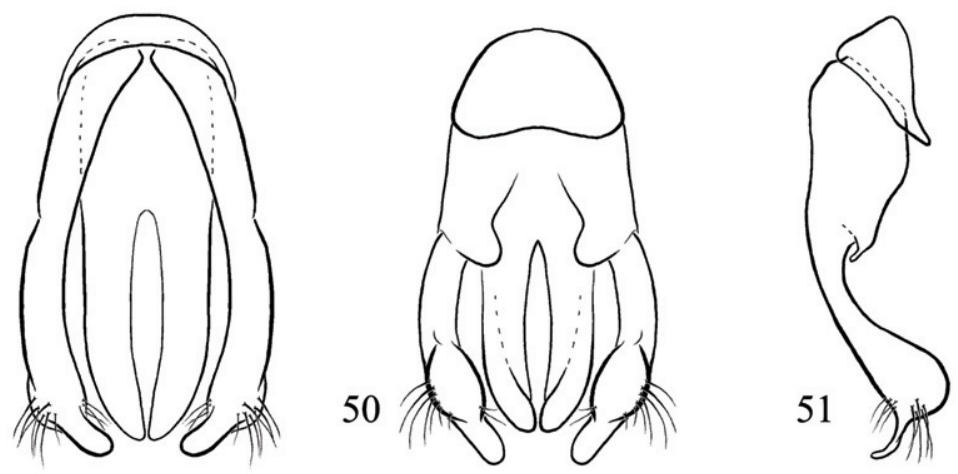

Figures 45-5I. Osmia nearctica, male holotype and paratype. 45 Dorsal view of genital capsule, partially covered by T6 and T7 (T7 apical margin is ripped) 46 Lateral view of gonoforceps 47 Ventral view of S6 48 Ventral view of S8 49 Dorsal view of genital capsule $\mathbf{5 0}$ Ventral view of genital capsule $\mathbf{5}$ I Lateral view of genital capsule, excluding penis valve.

tures separated by about half a puncture diameter; metepisternum with punctures less distinct, separated by up to a puncture diameter; hypostomal area anteriorly near angle, posterior half of gena, and legs with punctures shallowly impressed, sometimes elongated into oval shape; tegula with punctures minute, sparse medially and posteriorly, separated by up to four puncture diameters (up to six puncture diameters in some specimens); 
pronotum, metanotum, and lateral and posterior surfaces of propodeum with punctures less distinctly impressed and background integument weakly shagreened; propodeal triangle with dorsal fourth reticulate to lineate, lower three fourths strongly shagreened, dull. T1 anterior surface moderately shagreened, weakly shining, with scattered, sparse, minute punctures throughout; T1-T3 dorsal surfaces weakly shagreened, shining, with small punctures nearly contiguous to separated by 2.0 puncture diameters on basal three-fourths, minute and much more sparsely spaced on apical fourth (4.0-6.0 puncture diameters apart), apical margins with narrow region entirely impunctate (T1 with apical impunctate margin polished, ca. 5.0-6.0, Fig. 58; weakly shagreened, ca. 2.0-5.0 puncture diameters on T2-T3); T4-T5 much more strongly shagreened throughout, with small punctures nearly contiguous to separated by 3.0 puncture diameters on basal three-fourths, minute punctures separated by 2.0-6.0 puncture diameters on apical fourth, with apical impunctate bands ca. 3.0-4.0 puncture diameters in length.

Structure: Labial palpus four-segmented, second labial palpal segment ca. onefourth longer than basal most segment. Mandible with condylar ridge about twice thickness of outer ridge, strongly converging apically (Fig. 5); apical margin with four distinct teeth, third separated from second and fourth by carina, margin of third tooth forming distinct $\mathrm{V}$-shape with adjacent margin of second and forming weak concavity with margin of fourth, third tooth set back from second and fourth, very slightly directed inwards (Fig. 6); inner, ventral margin of mandible lacking distinct tooth, strongly diverging away from condylar ridge basally; mandible apically only slightly wider than narrowest point medially, first tooth subequal to, or very slightly longer than, second tooth, length between apical tips of second and fourth teeth 1.7 to nearly twice wider than apical tips of first and second teeth (Fig. 6). Clypeus with median truncation at apical margin linear to weakly concave, with truncation laterally weakly set off from remaining lateral margin of clypeus. F1 twice length of F2 or slightly more, remaining apical flagellar segments gradually increasing in length such that F10 about 1.2 times length of F1. Vertex behind lateral ocellus 2.5-3.0 OD in length. Genal width 1.0 to nearly 1.5 times that of compound eye in lateral view (wider dorsally). Preoccipital margin rounded, not carinate. Hypostomal carina moderately high, more or less level along length of head except reduced to obsolescence at angle, sometimes forming weak triangular projection posterior to angle. Malus forming pointed apical spine, this spine more or less a continuation of nearby edge of vellum. Foretarsal segments excluding basitarsal and apical-most segments with anterior lobes slightly longer than posterior. Midtarsal segments with anterior and posterior lobes of equal width, slightly swollen; hind tarsal segments not swollen. Hind tibial spurs slightly curved at apical tips, outer spur about a fifth shorter than inner. Hind basitarsal segment with lateral margins of outer surface parallel along most of length, converging apically.

Distribution. In the Nearctic, O. laticeps is known from Yukon east to Nova Scotia, and as far south as Ontario and Michigan. In the Palearctic, O. laticeps is known from Germany northwest to Sweden and Finland, east to Latvia and northern Siberian Russia (Müller 2010).

Comments. Osmia laticeps is oligoletic on Vaccinium (Ericaceae) (Nilsson 2009). 


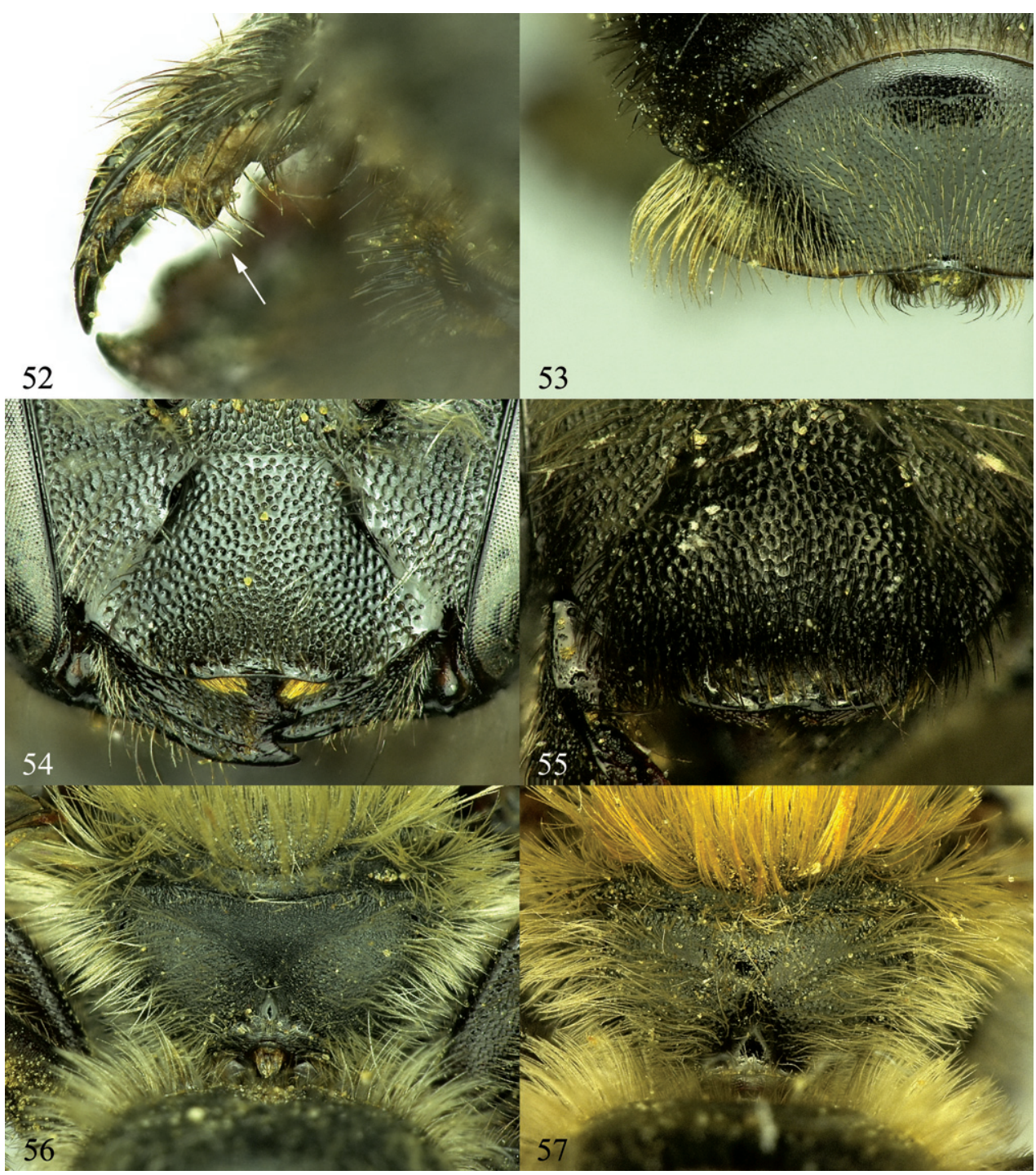

Figures 52-57. 52 Osmia inermis, female, ventral view of mandible showing tooth on inner margin of ventral surface 53 Osmia nigriventris, male, T5 and T6, showing flange on lateral margins 54 Osmia laticeps, female, clypeus with most of covering hairs removed 55 Osmia maritima, female, clypeus 56 Osmia inermis, female, posterior surface of propodeum and propodeal triangle $\mathbf{5 7}$ Osmia maritima, female, posterior surface of propodeum and propodeal triangle.

Material examined. CANADA: MANITOBA, Northern Region, 12 June 1952 (1 $\hat{0}$, Отtawa), 20 June 1930 (2ㅇ, $1 \hat{\jmath}$, Logan); NOVA SCOTIA, Kings Co., 24 May 1932, apple (10̂, OtтAWA); ONTARIO, Kenora District, 10 June 1964, Viola

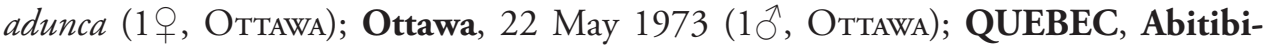
Témiscamingue Region, 24 May 1934 (1 $\odot$, Toronto); Nord-du-Québec Region, 9 
June 1956 (1ㅇ, OtтAWA); Bas-Saint-Laurent Region, 22 June 1916 (2ㅇ, ОттаWA);

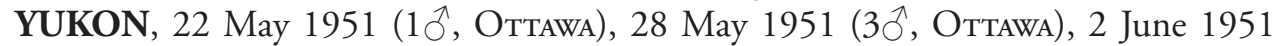

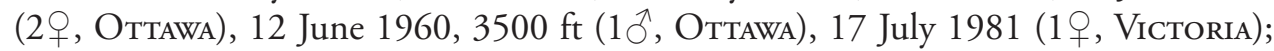
RUSSIA: Siberia, 11-15 July (19, OtTaWA); SWEDEN: Norrbotten Co., 6 July 1975 ( 1 \% , Uppsala); USA: MAINE, 15 June 1982 ( 19 , S T. Charles); MICHIGAN, Alger Co., 3-11 June 1982, sand pit (1ㅇ, 10, New YorK), 28 June 1982, Vaccinium myrtilloides (1ㅇ, Sт. Charles); Marquette Co., 10 June 1985, Gaylussacia sp. (1つ̂, St. Charles), 18 June 1983 (1ㅇ, St. Charles).

\section{Osmia (Melanosmia) maritima Friese}

Figs 7, 8, 55, 57, 59, 62-65

Osmia maritima Friese 1885: 85 [Lectotype female: Berlin]; Tkalců 1983: 152 [lectotype designation].

Diagnosis. Osmia maritima is one of two currently known species of the xanthomelana species group in North America (species with more or less shining ventral area of the propodeal triangle, apically widened mandible in females, and distinctly swollen gonoforceps in males). Females of $O$. maritima are distinguished from the other North American xanthomelana species group member, $O$. nearctica, by characteristics of the mandible, outer hind tibial spur, and clypeus: the mandible has a third tooth that is recessed below a distinct carina between the second and fourth teeth (Fig. 8) $(O$. nearctica with the third tooth in the same plane as the second and fourth teeth and no carina, Fig. 10); the outer hind tibial spur is strongly curved apically (O. nearctica with outer hind tibial spur weakly curved apically), and the apical truncation of the clypeus is not distinctly set apart from the lateral apical margin of the clypeus, Fig. 55 ( $O$. nearctica with the apical truncation forming a 90 degree angle with the lateral apical margin of the clypeus, Fig. 35). Females of $O$. maritima also have almost entirely black pubescence on the clypeus (significant amounts of light hairs throughout the clypeus in $O$. nearctica) and longer hair on the galea in dorsal view.

Males of $O$. maritima are distinguished from $O$. nearctica by their relatively long, sparse hairs on the lower surface of the flagellar segments $(O$. nearctica with these hairs microscopic) and weakly emarginate S2 (O. nearctica with S2 midapical margin not emarginate).

Distribution. In the Nearctic, O. maritima is known only from the Northwest Territories and Alaska. In the Palearctic, O. maritima is known from the Netherlands, Germany, Denmark, Norway, Sweden, and Finland east to Mongolia and through Russia to Far Eastern Siberia (Müller 2010).

Comments. We have not found any male specimens of $O$. maritima in the material of nearctic Osmia available to us. It is possible that once male specimens are discovered they may prove to be a distinct species from their palearctic relatives (if, as in $O$. aquilonaria, the novel diagnostic characters of the species are only found in the males); 


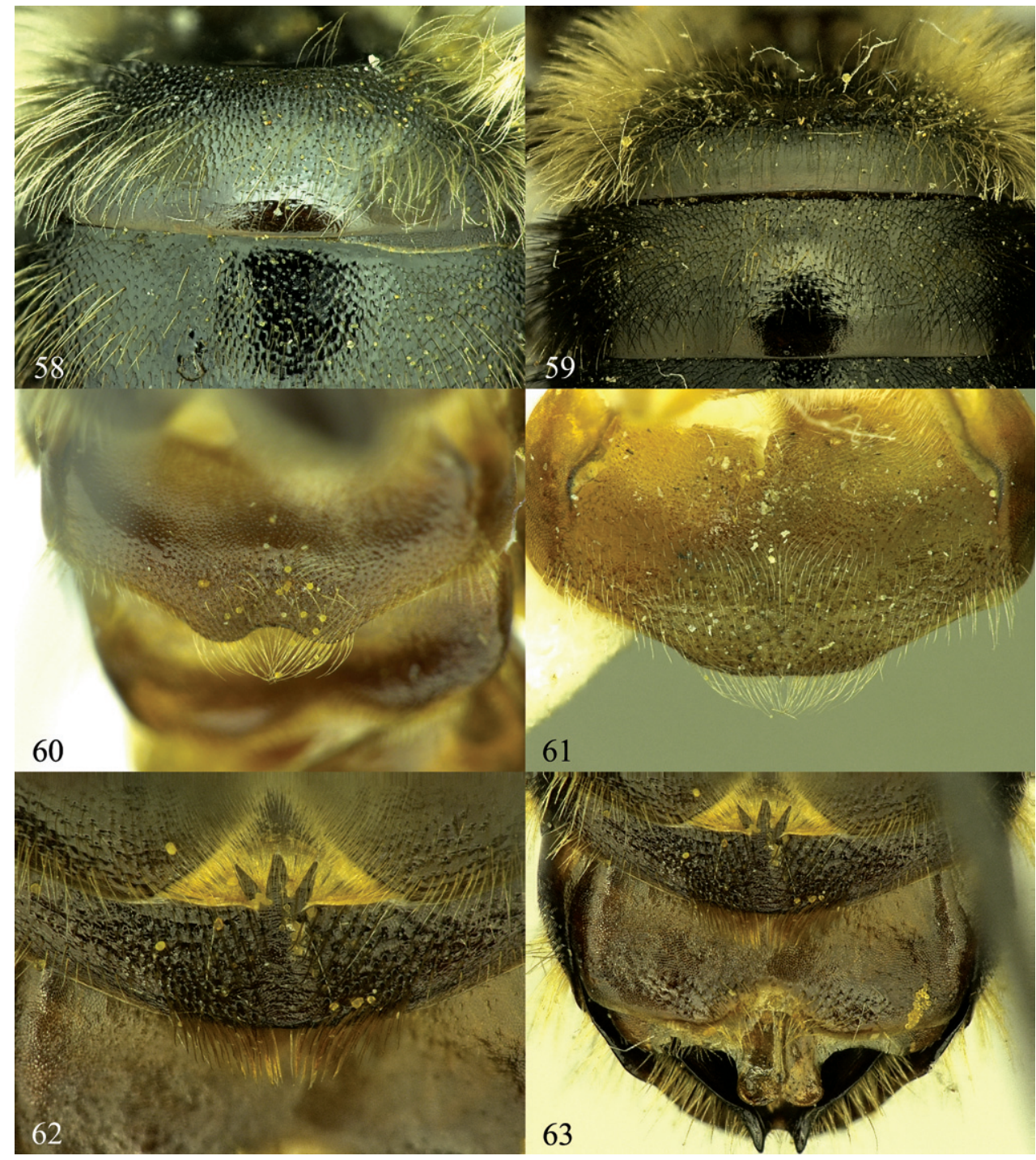

Figures 58-63.58 Osmia laticeps, female, T1 and T2 59 Osmia maritima, female, T1 and T2 60 Osmia inermis, male, S4 6I Osmia laticeps, male, S4 62,63 Osmia maritima, male 62 Detailed view of S3 and S4 63 S3-S6.

however, since a holarctic distribution is well established for other Osmia species (e.g., $O$. inermis and $O$. nigriventris), until proven otherwise we conservatively retain the name $O$. maritima for this species. Interestingly, there appear to be two female morphs of O. maritima. Specimens from Alaska and the Russian Far East share pale hair on the paraocular area and mesepisternum and scarcely sculptured apical areas on T2 and T3; females from the Northwest Territories and western Europe have dark hair on the paraocular area and mesepisternum and microsculptured apical areas of T2 and T3. 
Osmia maritima from the Palearctic is known to be polylectic and nests in sandy soil with cells composed of chewed leaves and sand grains (Müller 2010 and references therein).

Material examined. CANADA: NORTHWEST TERRITORIES, Inuvik Region, 17 June 1971 (1웅, Ottawa), 20-25 June 1971 (3우, Ottawa), 28-30 June 1971 (1 9 , Отtawa), 11 July 1948 (1q, Oтtawa); NETHERLANDS: Terschelling,

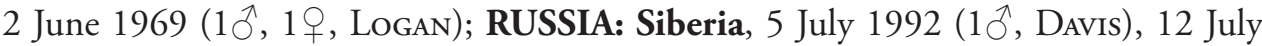
1992 (1 9 , DAVIS); USA: ALASKA, Fairbanks North Star Borough, 31 July 1985 (1 , DAVIS); Southeast Fairbanks Census Area, 21 June 1984, Oxytropis campestris (39, DAVIS); Yukon-Koyukuk Census Area, 17 May 1991, Dodecatheon frigidum (1q, DaVIs), 19 June 1992, Penstemon gormanii (1q, DaVIS).

\section{Osmia (Melanosmia) nearctica Rightmyer, Griswold, \& Arduser, sp. n.} urn:lsid:zoobank.org:act:E8E24354-14D3-463C-8505-F6E2002F401E Figs 9, 10, 33-51

Diagnosis. Osmia nearctica is one of two members of the xanthomelana species group in North America; characters to distinguish it from the other member of that group, O. maritima, are given under that species (see above).

In the Palearctic, O. nearctica is most similar to O. xanthomelana, but can be differentiated from that species by the following characters: In females, the propodeal triangle is shining but weakly shagreened throughout (Fig. 36) (O. xanthomelana with entirely polished, strongly shining lower half of the propodeal triangle), the outer hind tibial spur is only about half the length of the hind basitarsal segment (O. xanthomelana with outer hind tibial spur nearly three-fourths length of hind basitarsal segment), and the lower margin of the mandible has a distinct, translucent flange that curves away from the condylar ridge (O. xanthomelana with the lower margin of the mandible opaque, forming a ridge that is parallel to the condylar ridge). The hairs of the mesepisternum tend to be dark brown in $O$. nearctica, while in $O$. xanthomelana the hairs tend to be pale yellow to white, and the hairs of the hypostomal area tend to be denser in $O$. nearctica than in O. xanthomelana.

In males, the propodeal triangle is weakly shagreened throughout in $O$. nearctica (Fig. 41) (O. xanthomelana with entirely polished, strongly shining lower half of the propodeal triangle); the lower tooth of the mandible is only slightly longer than the upper tooth in $O$. nearctica (in O. xanthomelana the lower tooth of the mandible is much longer than the upper tooth and the entire apical margin of the mandible is conspicuously wider than the middle, approaching the look of male Acanthosmioides); T7 midapically has a shallower emargination in O. nearctica (Fig. 43) than in O. xanthomelana; the S6 midapical truncation is clearly emarginate in $O$. nearctica (Fig. 47) (O. xanthomelana with S6 truncation not emarginate); and the apical tip of the gonoforceps (apical to subapical swelling) is more rounded in O. nearctica (Figs 49, 50) (in O. xanthomelana the apical tip is more pointed). Osmia nearctica can be differentiated from $O$. maritima and $O$. alticola by the microscopic hairs on the underside of the 


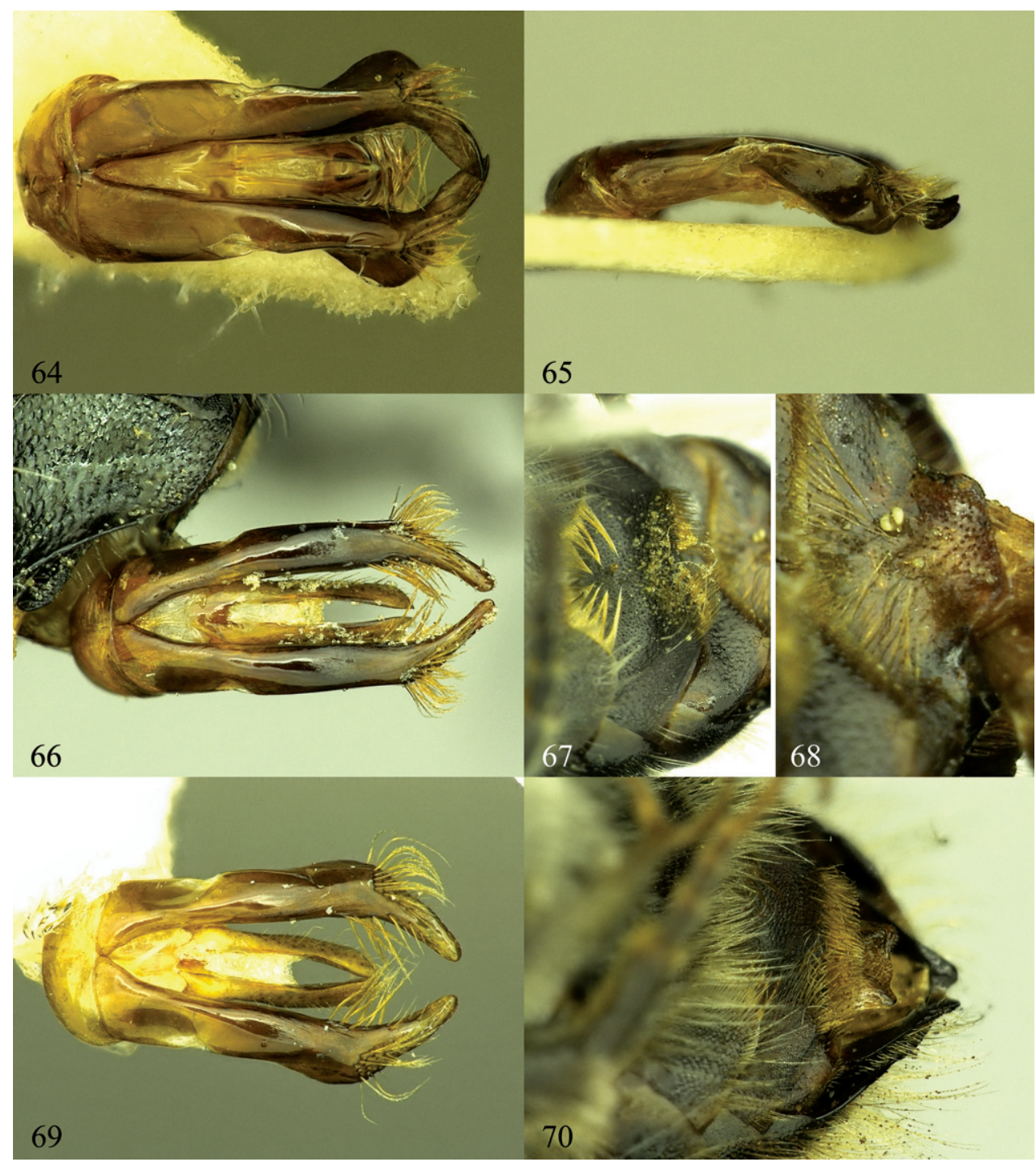

Figures 64-70.64, 65. Osmia maritima, male, genital capsule 64 Dorsal view 65 Lateral view. 66-68. Osmia steinmanni, male paratype. 66. Dorsal view of genital capsule 67 S3 and S4 68 S5 and S6 69, 70 Osmia svenssoni, male paratype. $\mathbf{6 9}$ Dorsal view of genital capsule 70 S4 and S6.

flagellar segments (O. maritima and $O$. alticola with conspicuous hairs about half the width of the flagellar segments).

Description. Female. Figs 9, 10, 33-38. Total length: 9.0-11.5 mm; forewing length: $6.5-7.2 \mathrm{~mm}$; length of lateral ocellus to preoccipital margin $0.6 \mathrm{~mm}$; length of lateral ocellus to compound eye $0.7 \mathrm{~mm}$.

Color: Dark brown to brown-black, sometimes with reddish overtones especially on mouthparts, labrum, mandible, flagellar segments, legs, and apical margins of 
T1-T5. Wings moderately infuscate, more strongly infuscate in marginal cell and distal to cells.

Pubescence: Clypeus below apical margin with lateral tuft of golden, medioposteriorly directed hairs. Brown, minutely branched hairs on most of body except as follows: white to yellow, minutely branched hairs interspersed with brown on outer surface of mandible, face excluding ventral third of clypeus and sometimes on vertex (and gena), and dorsal surfaces of T2, T5, T6; almost entirely white to yellow, minutely branched hairs on vertex (sometimes), mesoscutum, mesoscutellum, metanotum, dorsally on propodeum (excluding triangle), pronotal lobe, and dorsal surface of T1; brown, simple hairs interspersed with minutely branched hairs on most of body, except simple hairs lacking on dorsal mesosoma; simple hairs only (no branched hairs), golden on all tarsi and brown on scopa; brown, short, simple hairs evenly covering forewing. Galea and basal two labial palpal segments with hairs on lateral margins straight, 0.2-0.5 OD in length. Labrum with long hairs arranged in two curved, transverse rows, along subapical margin and approximately at midpoint, with additional fringe of shorter hairs at apical margin. Clypeus with hairs about as dense as on frons. Hypostomal area with hairs densely distributed across area, straight to weakly incurved at apical tips, 3.0-4.0 OD in length.

Punctation: Head and mesosoma with punctures nearly contiguous, more or less round, and moderately impressed except as follows: labrum mostly impunctate except near fringes of hairs; clypeus with impunctate midapical truncation about length of F2 or little longer (Fig. 35); mesoscutum posterior to median longitudinal sulcus with punctures separated by up to a puncture diameter; mesepisternum with punctures less strongly impressed, nearly contiguous to separated by about half a puncture diameter; hypostomal area near angle and legs with punctures shallowly impressed, sometimes elongated into oval shape; tegula with punctures minute, sparser medially and posteriorly, separated by up to three or four puncture diameters; pronotum, metepisternum, metanotum, and lateral and posterior surfaces of propodeum with punctures very weakly impressed, with background integument weakly shagreened; propodeal triangle with dorsal fourth reticulate, lower three fourths shagreened, weakly shining (Fig. 36). T1 anterior surface weakly shagreened, shining, with scattered punctures at dorsolateral angle; T1-T3 dorsal surfaces very weakly shagreened, shining, excluding apical impunctate margins with small punctures nearly contiguous to separated by 1.0 puncture diameter (on T1, Fig. 37) to separated between 1.0 to 3.0 puncture diameters (on T3); apical impunctate bands 2.0-4.0 puncture diameters in length. T4-T5 dorsal surfaces shagreened, weakly shining, excluding apical impunctate bands with punctures nearly contiguous to separated by 2.0 puncture diameters; apical impunctate bands about 5.0-8.0 puncture diameters in length. T6 with punctures minute, nearly contiguous, mostly obscured beneath dense hairs.

Structure: Labial palpus four-segmented, second labial palpal segment subequal to or ca. one-fourth longer than basal-most segment. Mandible with outer and condylar ridges of subequal thickness, parallel along length (Fig. 9); apical margin with four well-developed teeth, lacking carina separating third tooth from second and fourth, 
margin of third tooth forming distinct V-shape with adjacent margin of second and slightly smaller $\mathrm{V}$-shape with adjacent margin of fourth, third tooth more or less on same plane as second and fourth (Fig 10); inner, ventral margin of mandible lacking distinct tooth, diverging away from condylar ridge basally; mandible apically widened (ca. 1.7 times wider than median width), first tooth longer than other teeth, length between apical tips of second and fourth teeth subequal to slightly wider than apical tips of first and second teeth (Fig. 10). Clypeus apical margin with distinct truncation on middle half, this truncation with lateral corner slightly produced, forming weak protuberance relative to apical margin of truncation and forming ca. 90 degree angle with apical margin of clypeus lateral to truncation (Fig. 35). F1 twice length of F2, remaining apical flagellar segments gradually increasing in length such that F10 subequal to F1 or little longer. Vertex behind lateral ocellus 2.0-2.5 OD in length. Genal width 1.5 to nearly 2.0 times that of compound eye in lateral view. Preoccipital margin rounded, not carinate. Hypostomal carina moderately high, highest at about midpoint of hypostomal area posterior to angle and forming distinct triangular projection at this point, tapering to low carina or near obsolescence at angle. Malus forming pointed apical spine. Foretarsal and midtarsal segments excluding basitarsal and apical-most segments with anterior lobes slightly longer than posterior; hind tarsal segments not swollen. Hind tibial spurs weakly curved, outer spur about a fifth shorter than inner. Hind basitarsal segment with lateral margins of outer surface parallel.

Male. Figs 39-51. Total length: $8.6 \mathrm{~mm}(8.0-9.1 \mathrm{~mm})$; forewing length: $6.0 \mathrm{~mm}$ $(6.0-6.5 \mathrm{~mm})$; length of lateral ocellus to preoccipital margin 0.5 ; length of lateral ocellus to compound eye $0.6 \mathrm{~mm}$.

Color: Black to dark brown, sometimes with reddish overtones especially on mouthparts, labrum, mandible, flagellar segments, legs, and apical margins of T1-T6 and S1-S3. Wings mostly clear except weakly infuscate along leading edge of forewing, especially along dorsal half of marginal cell.

Pubescence: White to pale golden, minutely branched hairs on body except golden to pale golden, stouter, simple hairs on inner surfaces of tarsi, S4, and S6, and intermixed with white, branched hairs on mandible, lower gena, and outer surfaces of tarsi. Labrum with row of hairs across approximate midline, sparsely covered with hairs on apical fourth and with hairs forming short fringe at apical margin. S2 with hairs at apical third ca. 1.5 to $2.0 \mathrm{OD}$ in length. S3 with medially directed hairs filling entire emargination (hairs ca. 1.0 OD in length medially, 2.0 OD laterally) (Fig. 44). S4 with weakly defined, asetose longitudinal strip, otherwise covered with regularly spaced, simple, short, weakly distally hooked, golden hairs arising from papillate bases (Fig. 44). S6 midapical truncation with very sparse, short, simple hairs arising from papillate bases (Fig. 47).

Punctation: Head with punctures ovate to nearly circular, separated by one-fourth to one-half puncture diameter (up to 1.0 puncture diameter posterior to compound eye) and deeply impressed except as follows: labrum mostly impunctate on basal twothirds; clypeus with impunctate band along apical margin, about one-fourth length of F1; disc of clypeus, interantennal area, and paraocular area with punctures small, ovate, 
and nearly contiguous (punctures mostly obscured beneath dense hairs); hypostomal area anteriorly near angle with punctures weakly, shallowly impressed. Mesosoma with punctures more or less round, nearly contiguous to separated by up to a half puncture diameter, deeply impressed except as follows: mesoscutum immediately posterior to median longitudinal sulcus with punctures separated by up to one, sometimes as much as two puncture diameters; tegula with punctures minute, sparse medially, separated by up to five puncture diameters; pronotum, dorsal half of metepisternum and lateral and posterior surface of propodeum weakly shagreened, with moderately impressed, larger punctures; ventral half of metepisternum mostly impunctate, weakly shining; propodeal triangle lineolate to reticulate on dorsal third, shagreened and weakly shining on ventral two-thirds; legs with inner surfaces of femora and tibiae shining, with scattered smaller punctures. T1 with anterior surface very weakly shagreened, shining; T1-T2 with dorsal surfaces excluding apical margins weakly shagreened, shining; T3, T6-T7 dorsal surfaces moderately shagreened; T4-T5 dorsal surfaces strongly shagreened, dull; metasomal terga with apical impunctate margins polished. T1 dorsal surface with punctures minute, distinct and well-impressed, nearly contiguous to separated by a puncture diameter; apical impunctate margin ca. 4.0-5.0 puncture diameters in length (sometimes medially as long as 6.0-7.0 puncture diameters in length). T2-T7 with punctures minute, $\mathrm{T} 2$ with punctures separated by ca. 1.0 puncture diameter medially, successively posterior terga with punctures progressively becoming more widely spaced to about 3.0 puncture diameters apart on disc of T6; T2-T6 with apical impunctate margins 4.0-8.0 puncture diameters in length, T7 lacking apical impunctate margin. S1-3 with punctures minute, well-impressed, nearly contiguous to separated by ca. 1.0 puncture diameter. S4-S6 lacking distinct punctures, weakly shagreened.

Structure: Mandible with outer and condylar ridges converging apically; apical margin with two teeth, upper tooth distinctly shorter and wider than lower; inner, ventral margin of mandible very weakly diverging away from condylar ridge basally. Clypeus apical margin mostly linear except with weak irregular tubercles above tufts of setae below apical margin at each side. Flagellar segments subequal in length, except F1 slightly shorter than F2 and F11 slightly longer than F10. Vertex behind lateral ocellus $1.5-2.0 \mathrm{OD}$ in length. Genal width in lateral view ventrally subequal to, dorsally ca. 1.3 times wider than, width of compound eye. Preoccipital margin rounded, not carinate. Hypostomal carina relatively short, gradually tapering to near obsolescence at angle, not forming distinct tooth. Malus forming distinct apical spine. Foretarsal segments excluding basitarsal and apical-most segments with anterior lobes slightly more swollen than posterior. Mid- and hind tarsal segments not swollen. Midfemur with swollen projection on ventral surface. Hind tibial spurs weakly curved at apical sixth, outer spur ca. one-fifth shorter than inner. Hind basitarsal segment widening about a third from apical margin, with strong tooth on inner margin at widest point (Fig. 42). T6 midapically with wide, shallow emargination, forming ca. one-fourth of circle in outline (Fig. 43); T6 lateroapical margin slightly concave sublaterally, forming weak lobe. T7 midapically strongly emarginate, forming semicircle about as wide as, or slightly wider than, deep (ca. 1.5 OD wide; Fig. 43), with spines 
on either side of emargination rounded, basally nearly as wide as emargination width. S2 strongly convex, covering most of S3. S3 with midapical emargination one-third entire width of sternum and nearly as long as wide (Fig. 44). S4 with apical margin evenly convex, with very weakly defined midapical truncation (Fig. 44). S5 with apical margin evenly, weakly concave along median half of margin. S6 with midapical truncation one-fifth width of sternum, truncation slightly wider than deep, apical margin of truncation very weakly emarginate midapically (Fig. 47; S6 sometimes folded along longitudinal length, thus increasing appearance of midapical emargination); S6 with lateral edge strongly folded, bulbous in appearance in ventral view. Gonoforceps strongly swollen subapically, apical to swelling with flattened, narrowed process (Figs 45, 46, 49-51).

Distribution. Canada from Yukon, the Northwest Territories, and Nunavut southeast to Ontario and Quebec.

Holotype male. "[Canada] Norman Wells, N.W.T. [Northwest Territories], 13VII-1949, W.R.M. Mason// Holotype male Osmia nearctica Rightmyer, Griswold, \& Arduser" (OTTAWA)

Paratypes. CANADA: MANITOBA, Winnipeg Capitol Region, Kettle Rapid, near Winnipeg, 14 July 1917 (19, New York) ; NORTHWEST TERRITORIES, Dehcho Region, Hay River, 5 June 1951, P. R. Ehrlich (2q, OTTAWA); Inuvik Region, Reindeer Depot, MacKenzie Delta, 23 June 1948, W. J. Brown (1 9 , Otтawa), 16 July 1948, J. R. Vockeroth (1을 Ottawa); Sahtu Region, Norman Wells, 19 May 1953, C. D. Bird (19, Ottawa), 27 May 1953, C. D. Bird (1q, Ottawa), 12 June 1949, W.R.M. Mason (2q, Otтаwa), 3 July 1949, W.R.M. Mason (1 $q$, OtтAwa), 4 July 1949, W.R.M. Mason (1q, OтTAWA); NUNAVUT, Kitikmeot Region, Coppermine, 3 August 1951, S. D. Hicks (1 + , OtтAWA); ONTARIO, Thunder Bay District, Black Sturgeon Lake, 13 June 1961 (1ڤึ, OттаwA); QUEBEC, Nord-du-Québec Region, Rupert River, 10 July 1956, J. R. Lonsway (1亏े, OtтAwa); YUKON, Dempster Highway km 465, 15 July 1982, D. Wood (1, Otтawa).

Etymology. The name "nearctica" is derived from the Greek arktikous, meaning northern or arctic, and is in reference to the known distribution of this species in northern regions of the New World (i.e., Canada).

\section{Osmia (Melanosmia) nigriventris (Zetterstedt)}

Figs 11, 12, 53

Anthophora nigriventris Zetterstedt 1838: 465 [Syntype female: presumed lost (Tkalců 1995: 141)].

Osmia nigriventris (Zetterstedt); Nylander 1848: 260.

Osmia baicalensis Radoszkowski 1867: 80 [Lectotype female: Berlin]; Friese 1909: 126

[synonymy with O. dimidiata Morawitz]; Zanden 1991: 353 [Lectotype designation, rejection of synonymy with $O$. dimidiata Morawitz, synonymy with $O$. nigriventris (Zetterstedt)]. 
Osmia frigida Smith 1853: 142 [Male and female syntype series: London]; Sandhouse 1939: 35 [synonymy].

Osmia hudsonica Cresson 1864: 21 [Holotype male: Philadelphia]; Sandhouse 1939:

35 [synonymy].

Osmia corticalis Gerstäcker 1869: 331 [Lectotype female: Berlin]; Thomson 1872: 244

[synonymy]; Tkalců 1995: 141 [Lectotype designation (but see Nilsson 2009: 50)]. Osmia (Melanosmia) nigriventris (Zetterstedt); Schmiedeknecht 1885-1886: 79.

Osmia (Centrosmia) nigriventris (Zetterstedt); Sinha 1958: 244; Sinha and Michener 1958: 284 [revision].

Osmia (Centrosmia) nigriventris frigida Smith; Tkalců 1995: 141.

Diagnosis. Females of this species are known by the swollen clypeal margin (Figs 11, 12) (approaching the extreme look found in $O$. bucephala, but unlike in that species, there is no metallic coloration in the integument of the meso- and metasomata). Males are known by the strongly reflexed apicolateral angles of T5 and T6 (Fig. 53). Unlike in O. bucephala, the midleg tarsal segments $2-4$ are not modified or swollen, and S2 is unmodified (S2 of O. bucephala with a low tumescence bordered anteriorly and laterally by several rows of erect bristles).

Distribution. In the Nearctic, O. nigriventris is known from Oregon, Idaho, Wyoming, and Michigan north to Yukon and the Northwest Territories, east across Canada to Ontario, Quebec, and Newfoundland. In the Palearctic, O. nigriventris is known from France, Italy, and Slovakia north to Norway, Sweden, and Finland and east to Mongolia, northern China, and through Russia to Far Eastern Siberia (Müller 2010).

Comments. Osmia nigriventris is polylectic, with preference for Vaccinium (Ericaceae); it nests in old insect burrows in dead wood and constructs cell partitions and nest plugs with chewed leaves (Müller 2010 and references therein).

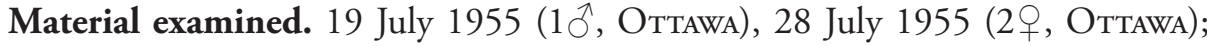
CANADA: ALBERTA, Alberta's Rockies Region, (1 + , OтTAwA), 21 May 1915 (1 ,

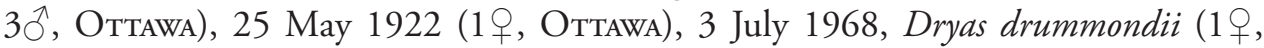

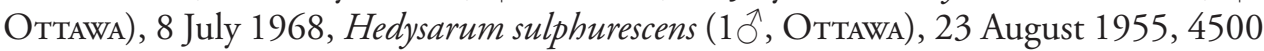

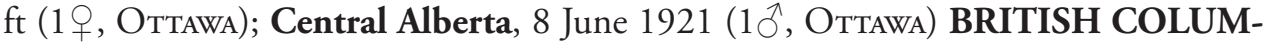
BIA, Stikine District, 6 June 1955, $2200 \mathrm{ft}$ (19, OtтаWA), 9 June 1955, $2200 \mathrm{ft}$

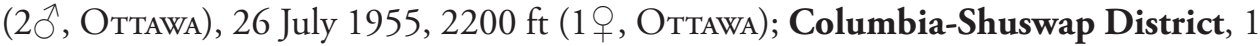
August 1950 (1 9 , ОттаWA), 1 August 1952, $6000 \mathrm{ft}$ (1우, ОттаWA), 2 August 1952, $6000 \mathrm{ft}$ (1우, Отташа); Peace River District, 11 June 1948 (10, Отташа), Thompson-Nicola District, 8 August 1943 (1 9 , ОттAWA); MANITOBA, Eastman Region,

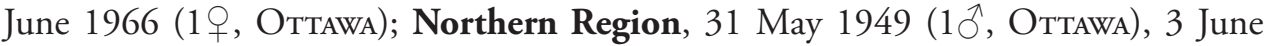

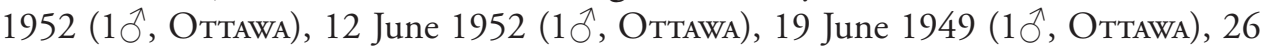

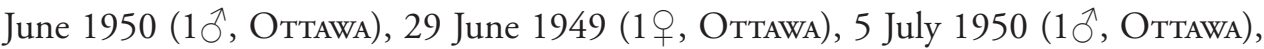

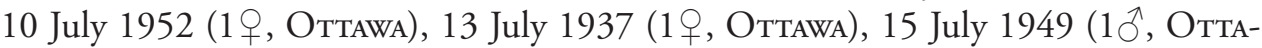
WA), 17 July 1937 (1 9 , OTTAWA); NEWFOUNDLAND AND LABRADOR, Great Northern Peninsula, 12 June 1951 (1 9 , OTTAWA); NORTHWEST TERRITORIES,

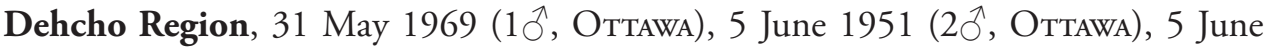




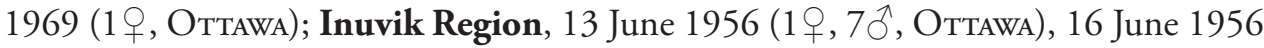

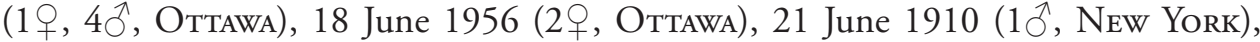

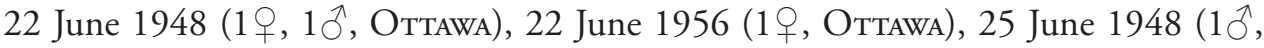

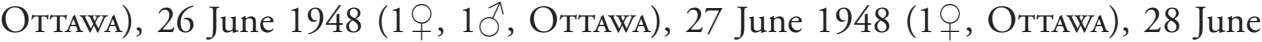

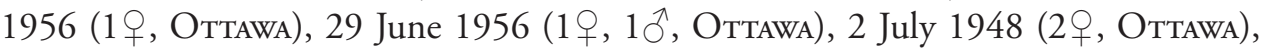
3 July 1956 (3우, Ottawa), 7 July 1948 (10, Ottawa), 10 July 1948 (1 + , Отtawa), 18 July 1948 (19, Отtawa), 25 July 1957 (19, Oтtawa); North Slave Region, 9

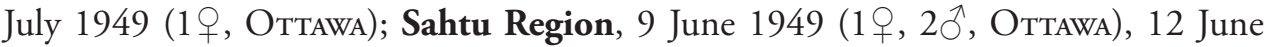

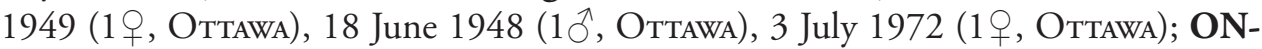
TARIO, 17 May 1962, Chamaedaphne sp. (1 ${ }^{\lambda}$, Toronto); Kawartha Lakes, 24 May 1964, Taraxacum officinale (1 ${ }^{\lambda}$, ОттаWA), 10 June 1964, Taraxacum officinale (10, OtтAwa); QUEBEC, Nord-du-Québec Region, 12 June-8 August 1987 (19, От-

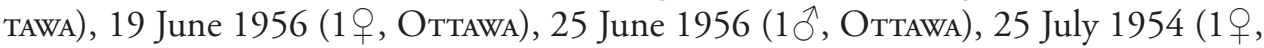
OtтaWA); Côte-Nord Region, 7 July 1948 (10̂, OttaWA); YUKON, 22 May 1951

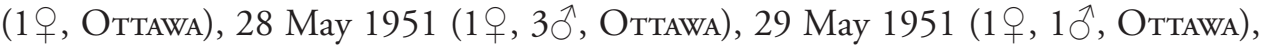

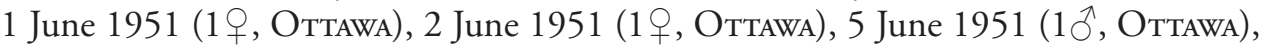

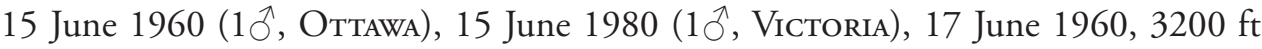

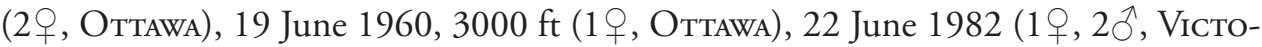

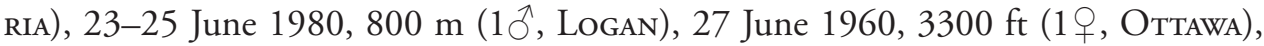
27 June 1984 (10, Victoria), 29 June 1984 (10․ Victoria), 1 July 1949 (1우, Vic-

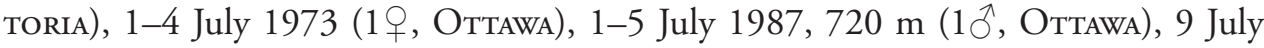
1983, 2300 ft (1ㅇ, Victoria), 9 August 1981 (1우, Victoria); RUSSIA: Siberia, 3 July 1992, Vaccinium vitis-idea (1 9 , DAvIs); USA: ALASKA, Fairbanks North Star Borough, 5-13 May 2009 (19, LogAN), 7 May 1982, Pulsatilla patens (1 ${ }^{\top}$, DAvIs), 5 June 1987, Hedysarum mackenziei (1ㅇ, Davis), 28 June 1987, Hedysarum sp. (1우, DAvIs); Southeast Fairbanks Census Area, 22 May 1985, Arctostaphylos uva-ursi (1우, Davis), 27 July 1982, Aster sibiricus (1우, Davis); Yukon-Koyukuk Census Area, 30 June 1991, Hedysarum boreale (19, DAvis); IDAHO, Lemhi Co., 20 July 1963 (19, 1§., Moscow); MICHIGAN, Marquette Co., 18 May 1982, Amelanchier bartramiana (1ㅇ, St. Charles), 19 May 1982, Amelanchier bartramiana (10̂, ST. Charles); MONTANA, Carbon Co., 22 June 1981, 6200 ft (1우, Boulder), 11 July 1963, $5200 \mathrm{ft}$ (1 9 , Boulder); OREGON, Deschutes Co., 19 July 1927, $5500 \mathrm{ft}(1+$, CorvaLLIS); WASHINGTON, Okanogan Co., 2 July 2004 (1 9 , LogAN); WYOMING, Fremont Co., 28 June 1990, $10400 \mathrm{ft}$, Arctostaphylos uva-ursi (10̂, Logan), 30 June

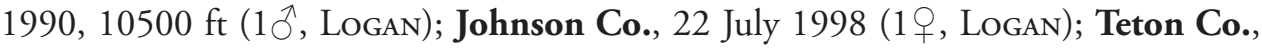
14 July 1930 ( $1 \partial^{\lambda}$, New York).

\section{Acknowledgements}

We are grateful to the individuals associated with the institutions listed above for providing access to the material described herein; in addition, we thank A. Müller (Zürich), D. Notton (London), K. Schneider (Halle), and O. Tadauchi (Fukuoka) for providing 
access to holotype and paratype material of palearctic Melanosmia. We thank H. Ikerd, E. Bourne, and C. Hunt for entering label data for these species into the U. S. National Pollinating Insects Database. Reviews by Lynnette Harris, Andreas Müller, Christophe Praz, Cory Sheffield, and an anonymous reviewer are greatly appreciated. This research was supported by the Utah Agricultural Experiment Station, Utah State University, and approved as journal paper number 8200 .

\section{References}

Benoist R (1922) Hyménoptères mellifères nouveaux pour la faune française. Bulletin de la Société Entomologique de France 91: 322-324.

Cockerell TDA (1910) Some insects from Steamboat Springs, Colorado-I. The Canadian Entomologist 42: 310-313.

Cockerell TDA (1912) Canadian bees in the British Museum. The Canadian Entomologist 44: $354-358$.

Cresson ET (1864) On the North American species of the genus Osmia. Proceedings of the Entomological Society of Philadelphia 3: 17-38.

Curtis J (1828) British Entomology; Being Illustrations and Descriptions of the Genera of Insects Found in Great Britain and Ireland: Containing Coloured Figures from Nature of the Most Rare and Beautiful Species, and in Many Instances of the Plants Upon Which They Are Found. Vol. 5. Privately published, London.

Dalla Torre KW von (CG de) (1896) Catalogus hymenopterorum hucusque descriptorum systematicus et synonymicus. Vol. 10. Apidae (Anthophila). Engelmann, Leipzig, viii + 643 pp.

Friese H (1885) Ueber einige seltene, zum Theil neue Apiden. Entomologische Nachrichten 11: 81-87.

Friese H (1909) Zur Synonymie der Apiden. Deutsche Entomologische Zeitschrift, Jahrgang 1909: 124-128.

Friese H (1911) Apidae I. Megachilinae. Das Tierreich, Lieferung 28. Friedländer, Berlin, xxvi $+440 \mathrm{pp}$.

Gerstäcker A (1869) Beiträge zur näheren Kenntnis einiger Bienen-Gattungen. Entomologische Zeitung 30: 139-184, 315-367.

Gussakovskij VV (1930) Hymenoptera Aculeata. In: Byalynitskiy-Birulya AA (Ed) Pamir-Expedition 1928. Abhandlungen der Expedition. Lieferung II. Zoologie. Akademie der Wissenschaften der Union der Sozialistischen Sovjet-Republiken, Leningrad [St. Petersburg], 67-88.

Haeseler V (1999) Zur Kenntnis von Osmia alticola Benoist 1922, Osmia maritima Friese 1885 sowie der für Mitteleuropa bislang unbekannten Osmia hyperborea Tkalců 1983 (Apidae: Osmia (Melanosmia Schmiedeknecht 1885)). Entomofauna Zeitschrift für Entomologie 20: 449-460.

Harris RA (1979) A glossary of surface sculpturing. Occasional Papers in Entomology, State of California Department of Food and Agriculture 28: 1-31.

Hicks B (2009) Observations on the nest structure of Osmia inermis (Hymenoptera: Megachilidae) from Newfoundland, Canada. Journal of the Acadian Entomological Society 5: 12-18. 
Hirashima Y (1973) Two new species of the genus Osmia from Japan and N. China (Hymenoptera, Megachilidae). Journal of the Faculty of Agriculture, Kyushu University 18: 63-68.

Kirby W (1802) Monographia Apum Angliae: An attempt to divide into their natural genera and families such species of the Linnean genus Apis as have been discovered in England. Vol. 2. Privately published, Ipswich, 388 pp., 18 pls.

Lovell JH (1909) The bees of Massachusetts: Osmia and Sphecodes. Entomological News 20: $122-126$.

Michener CD (2007) The Bees of the World, second edition. Johns Hopkins University Press, Baltimore, Maryland, xvi + [1] + 953 pp.

Morawitz F (1888) Hymenoptera aculeata nova. Horae Societatis Entomologicae Rossicae 22: 224-302.

Müller A (2002) Osmia (Melanosmia) steinmanni sp. n., a new bee species from the Swiss Alps (Hymenoptera, Apoidea, Megachilidae). Revue Suisse de Zoologie 109: 803-812.

Müller A (2010) Palaearctic Osmiine Bees, ETH Zürich, http://blogs.ethz.ch/osmiini [accessed 25.III.2010]

Nilsson LA (2009) The type material of Swedish bees (Hymenoptera, Apoidea) III. Entomologisk Tidskrift 130: 43-59.

Nylander W (1848) Adnotationes in expositionem monographicam apum borealium. Notiser ur Sällskapets pro Fauna et Flora Fennica Förhandlingar 1: 165-282, pl. 3.

Pérez J (1902) Espèces nouvelles de Mellifères paléarctiques. Procès-verbaux de la Société Linnéenne de Bordeaux 57: 57-68.

Radoszkowski O (1867) Matériaux pour servir à l'étude des insectes de la Russie. IV. Notes sur quelques Hyménoptères de la tribu des Apides. Horae Societatis Entomologicae Rossicae 5: 73-90.

Radoszkowski O (1874) Matériaux pour servir à une faune hyménoptérologique de la Russie. Horae Societatis Entomologicae Rossicae 10: 190-195.

Sandhouse GA (1939) The North American bees of the genus Osmia. Memoirs of the Entomological Society of Washington 1: 1-167.

Schmiedeknecht HLO (1885-1886) Genus Osmia Panz. In: Apidae Europaeae (Die Bienen Europa’s) per Genera, Species et Varietates. Vol. 2, [iv] + 205 pp. [867-1071] + [2, index], pls. 16, 17. Friedländer, Berlin, Pp. 1-110 (1885), pp. 111-205 (1886).

Schwarz M, Gusenleitner F, Westrich P, Dathe HH (1996) Katalog der Bienen Österreichs, Deutschlands und der Schweiz (Hymenoptera, Apidae). Entomofauna Zeitschrift für Entomologie, Supplement 8, 1-398.

Scopoli JA (1763) Entomologia carniolica, exhibens insecta carniolae indigena et distributa in ordines, genera, species, varietates. Methodo Linnaeana. IT Trattner, Vienna, 420 pp.

Sinha R (1958) A subgeneric revision of the genus Osmia in the Western Hemisphere (Hymenoptera: Megachilidae). University of Kansas Science Bulletin 39: 211-261.

Sinha R, Michener CD (1958) A revision of the genus Osmia, subgenus Centrosmia (Hymenoptera: Megachilidae). University of Kansas Science Bulletin 39: 275-303.

Smith F (1846) A supplementary paper containing descriptions of a few species of bees recently discovered or omitted in the descriptions of the genera to which they belong. The Zoologist 4: 1566-1568. 
Smith F (1853) Catalogue of Hymenopterous Insects in the Collection of the British Museum.

Part I. Andrenidae and Apidae. British Museum, London, [i] + 198 pp., pls. i-vi.

Smith F (1879) Description of New Species of Hymenoptera in the Collection of the British Museum. British Museum, London, xxi +[1]+ 240 pp.

Thomson CG (1872) Hymenoptera Scandinaviae. Skandinaviens Hymenoptera, 2:a. Delen. F Berling, Lund, 286 pp.

Tkalců B (1983) Die europäischen Osmia-Arten der Untergattung Melanosmia (Hymenoptera, Apoidea, Megachilidae). Věstník Československé Společnosti Zoologické 47: 140-159.

Tkalců B (1995) Die Bienen der Tribus Osmiini der Mongolei (Insecta: Hymenoptera: Apoidea: Megachilidae). Entomologische Abhandlungen 57: 109-147.

Ungricht S, Müller A, Dorn S (2008) A taxonomic catalogue of the Palaearctic bees of the tribe Osmiini (Hymenoptera: Apoidea: Megachilidae). Zootaxa 1865: 1-253.

Wu Y-R (1982) Hymenoptera: Apoidea. In: Chen S (Ed) The Series of the Scientific Expedition to the Qinghai-Xizang Plateau. Insects of Xizang. Vol. 2. Science Press, Beijing, 379-426.

Wu Y-R (2004) Ten new species of the tribe Osmiini from China (Apoidea, Megachilidae, Osmiini). Acta Zootaxonomica Sinica 29: 531-537.

Wu Y-R (2005) Fauna Sinica. Insecta. Hymenoptera Megachilidae. Vol. 44. Science Press, Beijing, [8] + xvi + 474 pp., 4 pls.

Zanden G van der (1991) Neue Arten der paläarktischen Osmiini und einige neue Fälle von Synonymie (Hymenoptera, Aculeata, Apoidea, Megachilidae). Linzer Biologische Beiträge, 23, 345-363.

Zetterstedt JW (1838) Hymenoptera. Insecta Lapponica, Vol. 1, Part 2. Leopold Voss, Leipzig, 317-475. 